\title{
Accounting and Pseudo Spirituality in Islamic Financial Institutions
}

\author{
Nunung Nurul Hidayah ${ }^{\mathrm{a}}$, Alan Lowe ${ }^{\mathrm{b}}$, Margaret Woods $^{\mathrm{c}}$
}

\author{
aston Business School, Aston University, Aston Triangle, Birmingham, B4 7ET, United Kingdom E- \\ mail address: $\underline{n . h i d a y a h 1 @ a s t o n . a c . u k ~}$ \\ ${ }^{\mathbf{b}}$ School of Accounting, RMIT University, 445 Swanston Street, Melbourne, 3000, Victoria, Australia, \\ E-mail address: alan.lowe@rmit.edu.au \\ 'Aston Business School, Aston University, Aston Triangle, Birmingham, B4 7ET, United Kingdom E- \\ mail address: m.woods@aston.ac.uk
}

\author{
Corresponding author: Nunung Nurul Hidayah \\ Aston Business School, Aston University, \\ Aston Triangle, Birmingham, B4 7ET, United Kingdom \\ E-mail address: $\underline{n \text {.hidayah1@aston.ac.uk }}$ \\ Phone number: +44 (0121) 2043105
}

\begin{abstract}
The global financial crisis was followed by calls for a transformation of conventional finance, towards more ethico-aesthetic models. One avenue was to consider the alternative aesthetic of Islamic financial institutions (IFIS). IFIs offer profit-loss sharing (PLS) schemes as a distinctive spiritual alternative to conventional investment products. IFIs ontotheology clashes with the epistemology of modern banking and finance. The accounting for PLS creates tensions due to practical complexity that militates against implementation of the authentic Islamic financial contracts. This paper seeks to identify the role of accounting in IFIs' practice of interpretation to resolve the struggles that have taken place around the implementation of PLS schemes as a means of spiritual based financial alternatives. We explore how IFls use accounting in rendering notions of spiritual/prophetic values applicable to practice or how it colludes against their implementation. Our study adopts a qualitative research methodology, framed around 40 interviews and observations of PLS implementation in IFIs in five Muslim countries in Asia and the Middle East, and one in the United Kingdom. We combine the literature on accounting and religion with the ideas/concepts from the literature on religion in organizations, political economy and Islamic law/finance. These perspectives enable us to better reveal how accounting works to reinvent spirituality. In our context we show how accounting mediates the conflicting interests and intentions that arise within the epistemological clashes that happen as the scared/religious strives to take its place in the capitalistic context of the conventional finance industry.
\end{abstract}

\section{Highlights:}

- The struggles IFls face in implementing profit and loss sharing schemes

- The tensions around PLS schemes induce the use of accounting to offer pseudo-spiritual finance

- Accounting role in mediating conflicting interests and intentions

Keywords: accounting in tensions; profit-loss sharing; pseudo spirituality; religious/spiritual ideals 


\section{Introduction}

In contrast to modern banking and financial institutions, Islamic Financial Institutions (IFIs) were established, in part, to offer alternative to the hegemony of liberal commercial banking (Kamla, 2009) and modern Western capitalism. IFIs propose a spiritual/transcendental approach to finance that combines elements of the logics and values of the market, religion, and social welfare (Maurer, 2012; Pollard \& Samers, 2013; Rethel, 2017; Tracey, 2012). Islamic values guide IFIs to forgo speculation, excessive uncertainty in financial transactions, and what is seen as a form of injustice in the debtor-lender relationship associated with the charging of interest.

Profit-loss sharing (PLS) represents the spiritual financial transactions that avoid money creation without entrepreneurial risk (DiVanna, Sreih, \& Ainley, 2009; Diwany, 2010; lqbal \& Mirakhor, 2007; Thomas, Cox, \& Kraty, 2005; Warde, 2010). Ideally, IFIs should promote real economic activities through equity financing and profit and PLS schemes (Diwany, 2010; Fang, 2014). PLS schemes are intended to facilitate partnership between capital providers and entrepreneurs in which they share both the risks and returns of an economic transaction. The notion of spiritual finance, such as PLS, in modern banking has been described as an imaginary landscape (Pollard \& Samers, 2013; Rethel, 2010).

In reality, IFIs operate within the context of well-established modern banking and financial markets where 'neoliberalism and market logic appear to be the only game in town' (Maurer, 2001 p.11). There is a clash between the ontotheology of IFIs and the epistemology of modern finance and banking. The PLS schemes become the imaginary landscape of IFIs and are continually subject to a process of ongoing negotiation and contestation (Rethel, 2017). The idea of shared risks and responsibilities in PLS schemes clashes with the strong roots of the limited liability conception of the modern corporation. These differences become an increasing pressure in the fierce competition in the markets where IFls operate.

Our paper seeks to explore the role of accounting in IFIs' practice of interpretation within the struggle these organizations face around the implementation of PLS schemes as a means of spiritual based financial alternatives. We focus on the following questions; how spirituality as a basis of alternative form of financial organizing is translated within organizational settings and how accounting is implicated in this process? What role(s), if any, does accounting play in rendering notions of religious/spiritual values applicable to practice or how it colludes against their implementation?

We provide an examination of the deeper nuances of the intersections between religion and accounting (Hardy \& Ballis, 2005; Jacobs, 2005; Shapiro, 2009) by exploring the role of accounting in responding to the tensions created by the infusion of spirituality into modern organization, such as IFIs. Our paper contributes to the literature on the mediating role accounting plays in addressing or 
revealing 'intentio (the end)' (Miller \& Power, 2013; Quattrone, 2015a) by showing how accounting

resolves the struggles between the sacred/religious ontotheology and the secular capitalistic epistemology of modern banking. We provide insight on how accounting works to manage the invention and reinvention of spirituality in modern financial institutions by creating pseudo spiritual financial products. This involves mediation among various interests and intentions to foster the innovative adaptation of spirituality.

IFIs use accounting in a fabrication, and commodification of the original PLS schemes. In our case, spirituality and accounting are combined in the negotiation of a balance between the religious/spiritual ideals and the situational requirements of product design/legitimation. Our study suggests that IFIs should reflect on the modification/appropriation of PLS schemes that induce complex financial engineering, and whether those financial products in the end provide an alternative or just another incarnation of capitalistic financial hegemony.

The remainder of this paper is structured as follows. Firstly, we offer our perspective based on a range of literature and ongoing debate around accounting and religion, the struggle to modify PLS schemes, and how accounting is engaged in organizing pseudo spirituality. Secondly, we outline the approach to data collection, our interpretivist approach to analysis, and the research context. In the following sections, we explore the way IFls engage in the creation of pseudo spiritual finance to encourage, but also to mimic, transcendence with the spiritual ideal. We complete the paper with conceptual and practical insights in the discussion and conclusion section.

\section{Accounting and Religion: Investigations of sacred and secular dichotomies}

Accounting research has partly explored the interaction between accounting practices and religion (Booth, 1993; Carmona \& Ezzamel, 2006; Jacobs, 2005; Laughlin, 1988; Quattrone, 2004). The sacred sense of human stewardship is incorporated in everyday accounting and budgeting practices (Irvine, 2005). It represents the accountability of material resources given by God (Jacobs \& Walker, 2004), and the guardianship role of accountants in the control of financial affairs (Jacobs, 2005; Parker, 2001; Quattrone, 2004).

Much of this research has been focused on the function of accounting within religious institutional contexts. Accounting plays an important part in controlling the theology and spirituality of many religious institutions, such as the lona community (Jacobs \& Walker, 2004), the Protestant Episcopal Church in the USA (Swanson \& Gardner, 1986), the Australian Uniting Church (Booth, 1993), and the Society of Jesus (Quattrone, 2004). The impact religious/spiritual values in the sociocultural and historical context of societies and organizations can be separated into two main streams of research. 
One stream of research that examined the sacred and the secular (the profane) dichotomy

became a dominant interpretive model for examining the situated accounting practices of religious organizations. This lens became influential following the seminal works of Laughlin $(1988,1990)$, Booth (1993, 1995), Faircloth (1988) and Swanson \& Gardner (1986). These studies focused mainly on the contrasting features of what was perceived as the secular function of accounting with the sacred objectives of religious organizations. They are premised on a clear separation of the boundaries of sacred and secular activities. Religious organizations are seen to buffer the sacred from worldly concerns as they attach religious meanings to secular activities.

The other stream, however, views sacred and secular as a continuum and inseparable in the complex environment of religious organizations (Hardy \& Ballis, 2005; Irvine, 2005). Those studies do not support the idea that religious organizations' sustainability is dependent on the effectiveness in facing pressures to change and the ability to slow down the intrusion of the secular. Accounting is not seen as a threat to the sacred values in some religious organizations (Jacobs \& Walker, 2004). It is these views of the blurring of boundaries between the sacred and secular that offer a useful lens into how non-religious activities, such as accounting, can be used to facilitate spiritual belief and practices of religious organizations.

The second research stream argues that sacred and secular imperatives are integrated or blended in religious organizations. This presents a more unified perspective on spirituality, where the sacred and the secular are constantly being redefined. Accounting is used in a pragmatic within the theological differences (McPhail et al., 2005) that enable alignment with the organizations' spiritual mission (Irvine, 2005), to retain control in the complex setting of religious organizations (Robbins \& Lapsley, 2015). Those studies, however, mainly focus on religious organizations or spiritual communities (Cordery, 2015).

With the increasing attention to spirituality in modern organizations, Tracey (2012, p. 119) calls for the exploration of how modern organizations employ spiritual/religious values. The extent to which accounting is implicated within the sacred-secular epistemological clashes can provide interesting insights. Such inquiry would further the discussion on the role of accounting as mediator in the tensions of submission to spiritual values but also to the stringencies of an economic perspective, as discussed in the following section.

\section{Accounting In-tension: Reinventing Spirituality to Mediate Conflicting Interests}

Foucault (1982, p. 331) argues that organizations experience the 'struggle against subjection, against forms of subjectivity and submission', which represents the difficulties in tying their own identity to organizational spiritual ideals. Spiritual ontotheology meets and clashes with the 
epistemology of modern organizations (Rethel, 2018). Spiritual/religious ideals in modern/secular be illustrated in the appropriation of spiritual ideals by secular organizations. Organizations seek to deconstruct religious ideals to create identifiable knowledge claims and moral guidelines to inform organizational actions.

This requires a continuous search for spiritual perfection, where religious guidelines are constantly classified, scrutinized, and reinvented to enable their implementation/reimplementation. 'Without this intentio (the end), there is no inventio (the means) and thus no rationes, no inventory, no invention, and no divine truth' (Quattrone, 2015a, p. 11) - the translation of religious rules within organizational activities requires continuous adaptation to suit different situations, logics and interests. The perfect translation of religious/spiritual ideals is somewhat left ambiguous as it needs to provide room for further pragmatic classification and reclassification. An adaptable spiritual purpose is required in order to embrace the various interests and intentions of organizational actors.

Collective effort in mediating conflicting interests is critical to the reinvention of a new mutual vision of spirituality in the modern organization. To embrace various interests, accounting plays a role in mediating practice, by creating a common narrative that bridges the various interests of different actors within the internal and external network of relations of the enterprise (Miller \& Power, 2013). Accounting plays a role as a mediating instrument of hegemonic domination of modern capitalism, serving as an engine of efficiency (Neimark, 1994; Quattrone, 2015b). Within the struggles of fitting spirituality into the capitalistic logic of modern organizations, accounting acts 'to count, not the visible, but the invisible' (Meyer, 1986, p. 351). Accounting in this case is used to interrogate the invisible nature of spiritual ideals to make it compatible with organizational interests. Using accounting, organizations craft and reinvent the spiritual rules (Quattrone, 2015a) to align the competing sacred and secular objectives with which they are faced.

Accounting practices enable the assemblage of various components with different ontologies, ideas and routines embedded in the religious/spiritual ideals and secular/commercial interests. It mediates clashes between theological and commercial logics. In the Renaissance period the calculation of interests was disguised in financial instruments such as bills of exchange in a way that differentiated it from usury may the across (Johnson, 2017). Accounting is implicated in a fertile arena for productive debate, mediation, compromise and innovative interrogation of what constitute the acceptable spiritual ideals in organizations. Accounting helps to speculate how spirituality could be managed in a way to link the interests of various actors within and beyond the boundaries of organizations (Chenhall, Hall, \& Smith, 2013; Quattrone, 2015a). Accounting, in this context of flux and incompleteness, is employed by actors to question what constitute spiritual infusion in modern 
organizational practices and facilitate an iterative and innovative search for spiritual perfection

(Busco \& Quattrone, 2017).

Accounting mediates the need for organizations to negotiate complex interests by offering 'pseudo religious' or 'pseudo spirituality' - innovative and adaptable spiritual ideals (Carroll, 2012; Halsall \& Brown, 2013) through which selectively reasoned spiritual stances or attitudes are reinvented (Avgerou \& McGrath, 2007). Accounting is both agent and outcome, both idea and practice to create greater autonomy in merging the religious/spiritual and secular/commercial arenas. Accounting serves a purpose in mediating the spiritual struggles due to its ability (through inscription) to be made mobile, stable, and combinable (Qu \& Cooper, 2011; Robson, 1992). The textual and graphical creativity of accounting inscriptions are influential in constructing the appropriatly persuasive spiritual practices, in order to articulate compliance with the pre-existing hegemony while infusing the religious ideals.

In the continuous reinvention of pseudo spirituality, the fabrication of accounting tools and techniques serves the purpose to mediate and reproduce the new spiritual vision that is accepted by various actors with different interests and logic in the modern organization. Fabrication represents processes that strengthen and stabilise accounting information as a fact-like but imperfect creation (Chua, 1995; Latour, 1999a; Locke \& Lowe, 2007). The fabrication of accounting tools involves chains of selection, translation and appropriation of spirituality to achieve acceptable pseudo-spiritual practices (Knorr-Cetina, 1981). The mediating role of accounting is temporary, and might change according to situational needs and interests, which includes reinventing spiritual beliefs as part of the products an organization offers (McGuire, 2009). Accounting mediates the act of 'commodification of religion', through which organizations leverage the labels/claims of religious authenticity (Carrette \& King, 2005). The mediating role of accounting is more of a permanent process than a stable outcome as part of maintaining spiritual legitimacy 'in-tension' within the ever-changing composition of organizational spiritual visions.

\section{Research Design}

\subsection{Data collection}

This study adopts a qualitative research methodology, consisting of interviews and observation on industry players' discussions/forums supported by extensive documentary analysis from leading IFIs. Qualitative methods enables us to offer a detailed illustration of the mechanisms and practices at work that provide insights into the ways in which accounting mediates the translation or modification of the original concept of profit and loss sharing (PLS) scheme into financial instruments/products in IFIs. Our data is draws from IFIs across 6 countries, including Malaysia, Indonesia, Abu Dhabi, Bahrain, Oman and the United Kingdom. We describe how and why 
accounting, is implicated in the reinvention and innovative interrogation of the central tenets of PLS schemes in the modern banking products. The qualitative methods adopted were crucial in enabling us to explore how and why accounting can mediate the appropriation and mutual translation of what constitutes the spiritual perfection of PLS instruments by creating 'acceptable' but spiritually dubious PLS instruments.

We collect data from interviews, documents including regulatory frameworks, and observations on industry discussions/forums related to PLS instruments. We conducted interviews with 40 participants from Indonesia, Malaysia, Bahrain, Abu Dhabi, Oman and the United Kingdom (UK), as shown in Table 1 below. We recorded the interviews, which ranged between 45 minutes to 2 hours. The interview participants included 17 IFIs managers, 4 national and global advisors, 7 Shariah compliance officers, 6 Shariah supervisory board members and 6 leading managers of national and international regulatory bodies. We selected participants who have 10 to 20 years working experience in the leading and/or pioneer Islamic banks and regulatory bodies that involve in the implementation of PLS schemes.

Table 1 Interviewees detail

\begin{tabular}{|lccccccc|}
\hline Countries & $\begin{array}{c}\text { Indonesia } \\
\text { (ID) }\end{array}$ & $\begin{array}{c}\text { Malaysia } \\
\text { (MY) }\end{array}$ & $\begin{array}{c}\text { Bahrain } \\
\text { (BH) }\end{array}$ & $\begin{array}{c}\text { Abu Dhabi } \\
\text { (AD) }\end{array}$ & $\begin{array}{c}\text { Oman } \\
\text { (OM) }\end{array}$ & $\begin{array}{c}\text { United } \\
\text { Kingdom (UK) }\end{array}$ & Total \\
\hline Manager (MG) & 6 & 2 & 2 & 1 & 1 & 5 & $\mathbf{1 7}$ \\
\hline Adviser (AD) & 0 & 1 & 1 & 0 & 1 & 1 & $\mathbf{4}$ \\
\hline $\begin{array}{l}\text { Shariah Compliance } \\
\text { (SC) }\end{array}$ & 3 & 1 & 1 & 0 & 1 & 2 & $\mathbf{7}$ \\
\hline Shariah Board (SB) & 1 & 1 & 1 & 1 & 0 & 2 & $\mathbf{6}$ \\
\hline Regulator (RG) & 2 & 2 & 1 & 0 & 0 & 1 & $\mathbf{6}$ \\
\hline Total & $\mathbf{1 1}$ & $\mathbf{7}$ & $\mathbf{6}$ & $\mathbf{2}$ & $\mathbf{3}$ & $\mathbf{1 1}$ & $\mathbf{4 0}$ \\
\hline
\end{tabular}

Our interviewees come from different socio-political environments and different institutional settings reflecting various economic histories and developmental experiences. However, our intention was not to compare such differences or how they may influence the orientations of the individuals. We sought to explore their experiences of the processes of translation and/or reinvention of the original PLS schemes into the contemporary IFIs PLS instruments. We look more into the way IFIs translate the PLS concept in the design of PLS based financial instruments. Our interest is in how the translation occurs (Cassell \& Lee, 2017; Latour, 1993), which implies the adjustment, displacement, rationalisation, reinvention, mediation, and recreation/repackaging of PLS products/instruments.

We have sought to explore the interviewees' experience in the process of translation, during their involvement in modifying, moulding and contextualising the religious/spiritual ideals that governed the original PLS schemes to suit the competing demands present in the contemporary financial environment. We explore what is represented in the translation of PLS schemes, and how 
accounting is implicated. In line with Callon (1984), we view translation as a process rather than a

result. We concentrated on the acts within the translation process, and demonstrate how cumulatively they have changed the character of PLS instruments and re-configure power and knowledge relations within the field of Islamic finance (Cassell \& Lee, 2017). We have sought to identify the way actors interpret the PLS schemes and how they made us of translation processes as an energy that enables movement (Latour, 1986, p. 267). The interviews were typically centred around three main themes: (1) the spiritual ideals of PLS schemes and the issues, challenges and tensions in implementing the original PLS schemes (2) their interpretation of Shariah/spiritual ideals in contemporary PLS schemes, (3), the rationalisation, modification, and adjustment processes which occur as Shariah compliance principles are applied in the PLS instruments, and (3) the arguments/rationales behind new forms of PLS schemes.

Table 2 Documentary Data

\begin{tabular}{|lll|}
\hline \multirow{2}{*}{ IFIs documents } & \multicolumn{1}{c|}{ Title } & \multicolumn{1}{c|}{ Related Information } \\
\cline { 2 - 3 } & Shariah pronouncements on PLS & $6 \mathrm{IFIs}$ \\
\cline { 2 - 3 } & Accounting guidelines on PLS & $6 \mathrm{IFIs}$ \\
\cline { 2 - 3 } & Product documentations on PLS & $6 \mathrm{IFIs}$ \\
\cline { 2 - 3 } & Financial reporting & $6 \mathrm{IFIs}$ \\
\hline Regulatory Framework & Shariah Standard on PLS & $\begin{array}{l}\text { AAOIFI and National Shariah standards } \\
\text { (Indonesia, Malaysia, Oman) }\end{array}$ \\
\hline & Central bank guidelines on PLS & Central banks of all 6 countries \\
\hline & Accounting standards/guidelines & $\begin{array}{l}\text { AAOIFI and National Islamic accounting } \\
\text { standards/guidelines of all 6 countries }\end{array}$ \\
\hline
\end{tabular}

We also collected documents related to PLS instruments from six IFIs offering commercial banking services in each of the six countries, as listed in Table 2 above. We explored the translations of PLS products, by examining IFIs' documents, such as Shariah pronouncements, product documentation, accounting guidelines, and financial reporting related to PLS instruments. We also explored the regulatory framework and accounting standards/guidelines on PLS instruments produced by central banks in the six countries and the international accounting standard setting body, Accounting and Auditing Organization for Islamic Financial Institutions (AAOIFI).

In addition, we carried out observations of industry discussions and debates on PLS instruments. We personally attended and observed two annual global Islamic finance conferences, one in Indonesia and one in the UK. We also observed several roundtable discussions and a Shariah scholars' forum on PLS instruments held by the regulators and the global network of IFIs in each of the selected countries. Those forums involved discussions among Islamic banking executives, Shariah scholars, and global Islamic finance regulators. Those forums provided a setting in which we could observe the views on the design and implementation of PLS schemes, the development of Shariah 
opinions along with updates on recently introduced PLS products/instruments. Finally we also

\subsection{Data analysis}

We transcribed and analysed the interviews using NVivo 9.2 qualitative data analysis software. We use NVivo for both data management and the early coding process of the interviews, which allows line-by-line coding of data. We carried out a thematic analysis of the narratives in our interview and documentary data. This is discussed in the following steps.

Step 1: Identifying empirical themes. The first step involved the development of first-order codes, in which the 40 interviews and documentary data were coded with NVivo 9.2 using thematic content analysis. This process enabled us to identify and extract the themes that were recurrent in the interviewees' accounts. The analysis was then strengthened by a further manual review of the codes, which at many points enable us to construct additional codes. The rationale behind the combination is to enhance research effectiveness and to emphasis the central role of the researcher in the analysis process, as coding and analysis 'is not a merely technical task' and that 'no mechanism can replace the mind and creativity of the researcher' (Marshall \& Rossman, 2010, pp. 218-219). From this first level of coding, we identified several themes, such as: the role of Shariah; the importance of PLS schemes; Shariah principles governing PLS products; pressures and challenges in implementing PLS schemes; conflicting demands influencing PLS modifications; the role of accounting reserves in maintaining PLS returns; income smoothing techniques in PLS instruments; combination and monetization of Shariah contracts; repackaging PLS schemes and other contracts to fixing return.

Step 2: Identifying conceptual categories. We reiterated the analysis of our data giving consideration of the literature on the role of accounting in spiritual/alternative forms of financing. We compared the themes from the data with one another. We consolidated the themes in higher conceptual categories from our second order coding themes, which included: Shariah/religious principles as a spiritual ideal (first level coding: the role of Shariah, the importance of PLS schemes, Shariah principles governing PLS products); the struggles and challenges faced by IFIs to implement of the spiritual ideal (first level coding: pressures and challenges in implementing PLS schemes, conflicting demands influencing PLS translations); and fabrication of PLS instruments (first level coding: the role of accounting reserves in maintaining PLS returns, income smoothing techniques in PLS instruments); and commodification of PLS instruments (first level coding: combination and monetization of Shariah contracts, repackaging PLS schemes and other related contracts) . 
Step 3: Identification of the outcome from our analysis. We identified the outcomes of our

analysis, which shows how IFIs sought to implement PLS schemes within the attendant epistemological and operational struggles. We identified that the accounting for PLS schemes creates a struggle, to balance financial market requirements with Islamic religious principles, that is resolved through the appropriation and translation of the religious principles guiding the offerings of PLS products. We identified accounting role in mediating the form of pseudo spiritual finance. These processes involved the IFIs in fabrication, commodification and the use of accounting practices to engage in the translation of original PLS instruments. We base our conceptualisations on the fabrication techniques discussed in the literature to portray the use of accounting as a mediating tool which IFIs use to resolve struggles around PLS schemes by using appropriated accounting techniques to show pseudo instruments as spiritual-like or but imperfect creation (Andon, Baxter, \& Chua, 2015; Busco \& Quattrone, 2015; Chua, 1995; Knorr-Cetina, 1981; Latour, 1999a; Locke \& Lowe, 2007)

In our analysis the data revealed IFIs' engagement and mobilisation of pseudo spiritual finance that shared similar form of spiritual commodification, in which organizations seek business and profit expansions by to leverage claims of religious authenticity and to label the fabricated PLS products as marketable goods (Badrinarayanan \& Madhavaram, 2008; Carrette \& King, 2005; McGuire, 2009; York, 2001). We have sought to explore how IFls rationalise the shifts of interpretation and meaning, which we apply to explain the translation of spiritual substance in PLS contracts. In turn, we uncovered the use of accounting in creating pseudo spiritual practices to promote mechanisms to deal with the struggles that take place in the crafting and blending that lies behind the creation of modern financial instruments alongside religious ideals, as discussed in the following section.

\section{IFIs Spirituality and the Struggle to Translate PLS Schemes}

\subsection{IFIs' religious ideals around PLS Schemes}

IFIs originate and seek to retain an identity of spirituality and religious vision (Ashforth \& Pratt, 2003; Tracey, 2012), which encompasses three primary dimensions: (1) transcendence or connection to a "higher power" than his/her self (Islamic religious belief); (2) holism and harmony or integration of one's identity/belief to the Islamic values/religious perspective; and (3) growth or the way Islamic religious or spiritual values provide a sense of self development and self-actualization. IFIs develop from the religious imperative to infuse Shariah as spiritual ideal into financial transactions and instruments. The elements of Shariah concepts are deployed in the governance of IFIs in the same way as it is intended to provide an ethical framework for individuals.

IFIs practices should be designed to avoid exploitations and injustice in the treatment of shareholders and customers alike (Bala Shanmugam \& Zahari, 2009). The religious imperative 
demands responsibilities of IFIs and a dedication to work to empower society through partnership

Spend your wealth for the cause of Allah, and be not cast by your own hands to ruin; and do good. Lo! Allah loveth the beneficent. (Qur'an: 2:195)

They were expert in business enterprise, keen and persistent in a variety of economic pursuits. They did not do so to amass wealth or save it for themselves; rather their aim was to spend their earnings in good causes. (Shatibi, Al-Muwafiqaat fi Usul alShari'ah, Vol. 2, p188, Cairo, Maktaba al Tijarah al-Kubra.)

These religious exigencies suggest that IFIs ought to engage with socio-economic development, especially in supporting entrepreneurs and partnering among businesses. The spiritual 
ideals ${ }^{1}$ stipulate venture investment and partnership contracts as a desired means of conducting business. PLS was meant to represent the essence of IFIs ethical financing. PLS contracts have long been offered as an alternative to debt-based financing through collaborative business that emphasizes the sharing of profits and losses in line with Islamic principles (Diwany, 2010; Warde, 2010). PLS is a contractual arrangement between two or more transacting parties, which allows them to pool their resources to invest in a project to share in profit and loss (Kamla, 2009). PLS schemes include mudharabah (a partnership between entrepreneurs (the provider(s) of labour) and capital providers. In mudharabah the partners agree how profits will be shared, and any losses to be borne by the capital providers. Alternatively in musharakah (an investment partnership, which requires each party to have capital contributions, with losses shared in proportion to the contributed capital) (Abdul-Rahman \& Nor, 2016; Diwany, 2010; Uusmani, 2002). The ideal concept of PLS schemes, however, is difficult to implement in modern banking and finance ${ }^{2}$. Accounting for PLS creates struggles for IFIs as discussed in the following sub-section.

\subsection{Struggles with Accounting for PLS Schemes}

IFIs' ideals and modern banking and finance have different objectives. The epistemology of contemporary banking and finance instruments militates against the ontotheology of PLS products (Maurer, 2003; Rethel, 2017). The socioeconomic and ethical objectives of PLS schemes are alien to the profit seeking and money creation practices of contemporary banking and finance. These epistemological clashes can be traced back to the development of the limited liability concept of the Joint Stock Company in the $19^{\text {th }}$ century, where the legal entity of corporation is separate from its members/shareholders (Hasanuzzaman, 1989). In 1882, the United State legislation for corporation removes the unlimited liability requirement imposed on the corporate shareholders to 'facilitate the formation of partnerships without the risks ordinarily attending them, and to encourage internal manufactures' (Bloom, 1882 in Presser, 1992, p. 155). It is believed that capital formation could be better accomplished by encouraging shareholders to invest by limiting their risks and liability.

\footnotetext{
${ }^{1}$ The interpretation of the religious rules or ljtihad in Arabic terminology is exercised through the consensus of the scholarly Muslim community (ijma), reasoning by analogy (qiyas), judicial preference (istihsan), public interest (maslaha), and custom (urf). The interpretation of Islamic law is in the form of an entanglement of both individual and institutional perspectives in introducing rulings for new cases. In order to arrive at a consensus (ijma), as one of the most powerful references in Islamic jurisprudence, each scholar within a certain Muslim scholars institution (i.e. International Islamic Fiqh Academy, the UK Islamic Sharia Council, Majelis Ulama Indonesia, Jawatankuasa Fatwa Kebangsaan Malaysia) undertakes an individual interpretation (ijtihad), and at a point in time they gather for the purpose of in-depth discussion and debate on the authenticity of texts, their meaning and implication, in order to achieve an agreement on a certain Shariah opinion (fatwa) (Diwany, 2010; Iqbal \& Mirakhor, 2007).

${ }^{2}$ Ideal PLS practices are found outside banking context in the form of venture investments. Those practices try to move away from the debt-based schemes/instruments of modern banking.
} 
Investors do not invest to lose their initial investment. In the limited liability context, investment risks

Figure 1 Comparison of Balance Sheet Elements

\begin{tabular}{|l|l|}
\hline \multicolumn{1}{|c|}{ Elements of IFIs' Balance Sheet } & Conventional Balance Sheet \\
\hline Assets & Assets \\
Liabilities & Liabilities \\
Equity of IAH from PLS contracts & Owners' Equity \\
Owners' Equity & \\
\hline
\end{tabular}

On the contrary, PLS schemes require a risk taking spirit and a higher degree of monitoring and cost of operation. Accounting for PLS schemes clashes with conventional accounting concepts (Maurer, 2002). Conventional accounting's entity theory is not conducive and conflicts with the reporting of PLS schemes in the balance sheet. Under PLS schemes, IFIs regard depositors as investment account holders (IAH)/investors who contributes a certain amount of capital in return for a percentage of the profit or loss based on their deposits/investments. This requires IFIs to manage and invest IAH investments in productive enterprises. As shown in Figure 1, IAH funds cannot be 
considered as a liability, as IFIs are not obliged to return initial investment in the case of loss since IAH do not enjoy powers and ownership rights (Atmeh \& Ramadan, 2012). In that case, by offering PLS schemes IFIs' balance sheet should show a different feature, which makes it difficult for IFls that operate within the modern banking and finance hegemony.

From a conventional accounting perspective, subject to the separation of owners and entities, the depositor is regarded as customer who is insulated from any business decision-making (AAOIFI, 2010; Maurer, 2002). Conventional banking and finance is limited to intermediary services for depositors. In that case, savings products constitute a liability. In this context the bank is only obliged to act in the interest of shareholders. The bank obligation is limited to providing fixed interest return to customers, which require simple accounting calculations. On the contrary, PLS schemes pose income calculation issues.

PLS schemes also provide the opportunity for investors/IAH to invest their money in restricted or non-restricted types of projects. There are several accounting issues with these types of PLS investment. IFIs need to identity the entity's assets. There are confusions as to whether IFIs must measure the entity's assets based on the real value of the assets, the initial value of investments, or some other liberal approach such as investment values with inflation adjustments or projected liquidation values (Maurer, 2002). In this case, the IFIs should also carefully avoid the possibility of interest (riba) element hidden/integrated in some of those methods. This creates contextualization issues from the accounting point of view, particularly on how to delimit, bound and abstract from the practice of IFIs' investment activities for IAH and IFIs' shareholders.

PLS products also create complexity in the income recognition for IFIs when operating in the logic and hegemony of conventional banking. The agency of PLS schemes is dispersed into multiple agencies for various proprietors (IAHs and IFIs' shareholders). Income becomes disaggregated from 'temporally fixed into contemporary assessments of cash equivalencies, in a continuous and real time marking to market' (Maurer, 2002, p. 656). The accounting for PLS creates struggles to cope with the constant and indefinite valuation of assets for various shareholders and IAHs. The practical accounting complexities create tension as to whether IFIs can fulfil the imaginary dream of PLS schemes, when it cannot easily play in a market wholly demarcated from contemporary banking. Within this epistemological and contextual struggle, accounting is implicated in IFI efforts to mediate conflicting interests and resolve struggles by constructing pseudo spiritual practices as discussed in the following section. 


\section{Pseudo Spiritual Finance: Organizing an Alternative Profit and Loss Sharing Contracts}

... It is difficult for banks to implement profit and risk sharing contracts because the risks are very high...especially when it is associated with operating and monitoring costs, production costs, current economic conditions, the issue of asymmetric information, adverse selection and moral hazard..." (MG1 - MY)

IFIs adherence to a spiritual agenda to provide equity-based finance through PLS schemes is found to be an on-going search and reinvention. The accounting of equal sharing of profit and loss/risk has creates struggles for IFIs as it clashes with the modern conceptions of entity theory and limited liability. In practice, market interest and logic shape the way IFIs perceive the high level of risks and the lack of capital security involved in the PLS schemes. The conflicting interests and the practical complexity in applying the original PLS schemes influences IFIs' appetite to reinvent an acceptable vision of PLS products, as narrated below.

The original dreams of Islamic finance was a double investment structure, where depositors would invest their money with the bank, and the bank would invest that money to businesses, and there would be a sharing of risks, and the profit will be shared with the depositors. But, that's not always being lived up to. There is a question whether people want that level of exposure. (AD2 - UK)

As a modern business, the primary function of IFIs is to generate as much return to shareholders as conventional banks. The economic imperative of modern banking places IFIs under pressure to increase profit year on year, to add value to shareholders' investments. At the same time, to follow the religious orders, Islamic banks cannot involve in highly leveraged risk transferring instruments as conventional banks. This requires IFIs to resolve the spiritual struggles.

During this short span of time, IFls have succeeded in formulating many innovative risk-sharing instruments that have enabled them to compete with their conventional counterparts (MG1 - AD)

Using accounting techniques, IFIs engage in fabrication and commodification of religious orders guiding PLS schemes to reinvent a form of pseudo spiritual finance. Pseudo spiritual PLS is reconstructed in an innovative manner suitable to the modern banking systems by engaging in fabrication of accounting tools/techniques and commodification of the fabricated spiritual products, as discussed in the following two sub-sections.

\subsection{Fabrication: how accounting creates a new vision of PLS instruments}

IFIs engage in the fabrication of accounting tools and techniques to guarantee IFIs and shareholders investments. Ideally, both the bank/investors and entrepreneurs involved in the PLS transaction share any profit and potential risks resulting from the PLS venture. However, the dyadic 
relationship in such contracts, involves incentive problems and issues of asymmetric information the investor/capital provider in monitoring the efficiency of capital investment and business processes of the agent/client. Pseudo spiritual PLS enables to IFIs to ensure investors' initial capital and returns of investments are protected from the relatively high risk of venture type investments in PLS contracts/products (Abdul-Rahman \& Nor, 2016; Uusmani, 2002).

The original PLS schemes creates issues for IFIs as it contradicts conventional retail banking accounting logic, where a bank's losses are not directly passed on to depositors. The depositors' principal investments are usually preserved. Conventional banking and finance provides financial protection and indemnity from losses for individual capital providers/depositors/investors. The lack of capital protection makes IFIs products less attractive compared to their conventional counterparts. This requires IFIs to rely on the strength and stability accounting information as a fact-like but imperfect creation to help create spiritually based financial products (Chua, 1995). The fabricated reserves and income smoothing techniques that are used to guarantee the initial capital and return of investments mediate the conflicting accounting logics. IFIs have sought to find remedies to the incompatibility between religious reference and the market appetite surrounding profit and risk contracts/transactions. As discussed in the quote below, IFls argue that the risk profile of investors/depositors be similar to that of conventional banking and finance.

Shari'ah, as authentically derived from its sources of Al-Quran, Al-Sunnah, Al-lima' and Al-ljtihad, has ordained that both categories of contracts of profit sharing and contracts of exchange are permissible subject to the elements and conditions of each individual contract...Any bank or financial institution is free to choose to implement any form of contract from either categories for any of its operations in accordance with its own circumstances, and in keeping with the Quranic doctrine of "mutual willingness" of the two contracting parties as well as the doctrine of personal freedom of choice to enter into any form of contract...as long as the contract is allowed by Shari'ah. (SCO1 MY)

The scenario described above is an example of how IFIs rationalise the application of spiritual ideals in the development of PLS contracts to suit the practical circumstances in which IFIs are operating. IFIs must consider the structure of their retail operations, to take into account that capital providers/depositors are unlikely to be willing bear any losses on their deposits. The commercial logic guides IFIs to provide security over customer investments, as IFIs face stiff market competition with convetional banking and finance. The income smoothing techniques used by IFIs are somewhat outside of the conventionally understood Shariah boundaries of PLS contracts. However these practices may be seen as inevitable if IFIs are to gain customer trust through their ability to provide stable returns to retail investors. As part of these processes of achieving fabrication, the income smoothing practices enable IFIs to construct socially situated practices of profit and risk sharing 
transactions. The use accounting reserve, as shown below, enables IFIs to achieve the desired ends

by moving the outcomes of the PLS transactions closer to those structure of conventional banking.

Accounting reserves, which includes a profit equalisation reserve and investment risk reserve are component of equity (of either investment account holders (IAH) and/or shareholders) and is constituted by appropriations made out of income...(Accounting guidelines of several IFIs on PLS return)

Profit equalisation reserve - This is the amount appropriated by the Islamic bank out of the mudharabah income, before allocating the mudharib [investor/capital provider] share, in order to maintain a certain level of return on investment for investment account holders and increase owner' equity." (AAOFI Financial Accounting Standard 11, paragraphs 15 and 16)

IFIs use such reserves to guarantee the return on PLS products. IFIs utilise two types of provisions/reserves that reduce the unique risks related to PLS transactions, namely a profit equalization reserve and an investment risk reserve. The use of these reserves acts as income smoothing practices and show how IFIs modify PLS scheme in order to secure a stable IAH profits. These practicea are widely used across IFIs and have become codified as a general accounting standard by the international regulatory bodies of the industry and the central banks in the six countries studied. The Accounting and Auditing Organization for Islamic Financial Institutions codified this accounting treatment on PLS return in their standard/guideline (AAOIFI financial accounting standard No.11 and Islamic Financial Service Board (IFSB) Guidance Note No.3 on profit smoothing).

\begin{abstract}
A typical retail Profit and Loss Sharing Investment Account [PLS in IFIs] involved maturity transformation: account holders can withdraw their money faster than the bank can realise the underlying assets, typically term loans. So if the bank cannot match the rates of return available to account holders elsewhere... it may suffer liquidity squeeze or even a run... From the standpoint of financial stability, therefore, smoothing mechanisms like profit equalization reserve do have their attractions (MG2 $-M Y)$
\end{abstract}

The profit equalization reserve and investment risk reserve consist of amounts set aside to meet future expected payments to investors/capital providers. Profit equalization reserve is allocated to maintain a certain level of return on investment for the investors, while investment risk reserve is designed to stand against future losses for the capital provider. Profit equalization reserve represents appropriations from both IFIs' and investors' profits, whereas the investment risk reserve is exclusively made up of excess investor's returns, IFls do not contribute its own excess returns into the investment risk reserve. In the UK, for example, the regulator insists that deposits should be guaranteed in the way deposits with conventional bank are. An Islamic finance global adviser from Bahrain suggests fabrication of the original PLS contract using profit equalization reserve, IRR and investment guarantee scheme. 
"That's not part of the Islamic models. You're not having your deposit guaranteed and get it back when the banks become insolvent. The position at the moment is that the guarantee is offered, and it's the customers who decide to waive it when the banks become insolvent. Another question is, how many of the customers at that stage would be willing to give up the guarantee return of their deposits. (AD1 - BH)

IFIs understand that such smoothing practices are not part of the Islamic model, but in order to satisfy stakeholder desires, they follow the dominant financial logic in the market. The introduction of profit equalization reserves and investment risk reserves into IFIs (as discussed in AAOIFI standard No.11 and IFSB Guidance Note No.3 on profit smoothing) enables IFIs to compete with the conventional banking industry. It provides a shield that IFIs can use to protect their risks such as: displaced commercial risk; withdrawal risks and reputational risks. Several accounting standard setting and regulatory bodies concerned with IFIs in different countries have agreed to codify IFIs translation to the original contract.

Hibah could be considered a 'constructive obligation' under MFRS 137, if the bank has an established practice of paying out a base amount to account holders. In this situation, it should be recognised as a liability equal to the 'best estimate' of what is expected to be paid. If the criteria for constructive obligations are not met, once hibah payments are declared, banks should apply general accounts payable and liability recognition and measurement requirements in respective standards to correctly account for the hibah. (Malaysian Accounting Standard Board Discussion Paper i-3)

IFIs in Malaysia represented in the above discussion paper, and other countries including Indonesia, Bahrain, and Pakistan translate the PLS schemes to suit local market preferences. IFIs translation of PLS contracts involves various income smoothing techniques, including hibah (gift), profit equalization reserve, investment risk reserve, or two tier contracts (where IFIs play a mediatory role) to transfer the risks from IFIs to investors/entrepreneurs, or the extreme approach of fixed return in profit and risk sharing contracts to guarantee the return on PLS investments, as shown in the following view.

We are very innovative by having mudharabah [profit and risk sharing schemes] with fixed return, [this is] a genuine style of our jurisdiction.... regulation is not restrictive, enough to ... [prevent] us hav[ing] many innovative and genuine tools... we don't want to get bored [restricted by] the complexity [risks and investment return uncertainty] of the structure [PLS schemes, including mudharabah and musharakah]... (MG3 - ID)

The application of fixed return in PLS as discussed above contravenes the spiritual nature of the scheme, which suggests that the return on the venture/investments is varied depending on the outcome of the investment or venture. The profit equalization reserve/investment risk reserve/gift or other smoothing techniques are used to mediate the recontextualisation of PLS schemes. IFIs 
involve chains of selection, translation and appropriation of spiritual ideals to reinvent PLS with a smoothing teachniques to guarantee PLS investment returns. By engaging in the fabrication of PLS investment IFIs mediate the various interests of market players to achieve fixed return from PLS investments. The pseudo PLS schemes represent a technique to achieve a selectively reasoned or modified spiritually based financial alternative (Avgerou \& McGrath, 2007; Halsall \& Brown, 2013; Munro, 2014) via a combination of both the spiritual realm and practical reasoning to create a modern form of spiritual domination at a distance (Latour, 1999b, p. 223; Lowe, 2001; Robson, 1992). Here, accounting mediating role resolves the practical and contextual struggles created by the original PLS accounting.

\subsection{Commodification: how accounting leverages the religious authenticity label}

If a bank has the Islamic label then people tend to trust it. If it doesn't then it tends to get less of a take up. If an Islamic bank drops the Islamic label, from a PR perspective, I think that would probably be a mistake. The label is what is making it uniquely attractive at the moment. (AD2 - UK)

The struggles for IFls to implement PLS scheme and the pressures to sustain a competitive market position lead to an engagement in spiritual commodification, which seeks ever extended markets, new sources of marketable goods, and expanding profits (McGuire, 2009; York, 2001). IFls' label of providing spiritual financial alternatives are leveraged to reinvent and repackage pseudo spiritual products (McGuire, 2009). In doing so, accounting is used to leverage claims of religious authenticity by selling-off the fabricated products/services to customers or other stakeholders (McGuire, 2010). Accounting information helps to leverage the label IFIs' assets and financing profile. These processes operate in order that fabricated Islamic financial instruments are constructed with similar features to debt-based instruments in conventional banking and finance.

At least in part, IFIs have been able refocus the emphasis on PLS contracts into commodified contracts such as tawarruq (monetization/sales and buy back transactions), bay' bi thaman ajil (sales with installment contracts), bay' al-inah (sale with immediate repurchase/sale with buy back transaction), or bay' ad-dayn (sales of debt certificates). The IFSB Stability Report (2016) shows a declining trend of PLS product share since 2008. The report describes that the biggest drop in PLS composition was witnessed in Malaysia. Since the Islamic Financial Services Act 2013 prohibits Islamic banks from adding any facilities that would smooth the returns to the capital holders, which removes the deposit protection to PLS types of deposits, the PLS share in Malaysia dropped from 40.87\% in 2013 to $23.48 \%$ in 2014 . The preliminary financial highlights of Malaysian sample banks in 
the second quarter of 2015 indicate that the PLS product share has declined further, to $12.95 \%$.

Similar to Malaysia, the United Arab Emirate's PLS share is also declining, from more than $70 \%$ in 2008, it shrank to 50.28\% in 2013 and 42.59\% in 2014.

Any bank or financial institution that operates within that limit is then in complete compliance with Shari'ah, and is "Islamic" irrespective of whether it liberally implements the contract of exchange (RG1 - MY)

Similar to the view presented above, PLS-based financing has to be appropriated from the original spiritual ideals to suit the market appetite (Abdullah, 2012; Maurer, 2002). The IFSB Stability Report (2016) shows that IFIs are now inclined towards alternative sale-based fixed profit deposit products (e.g. commodity murabahah term deposits - a fixed profit rate of return via the buying and selling of commodities as an underlying asset in a sales and buy back transaction) to be able to meet the demand for capital and profit-guaranteed term deposit solutions (Iqbal \& Molyneux, 2016).

The client approaches [an Islamic financial institution] or its affiliate (the 'Bank') and expresses its desire to purchase certain Shariah compliant commodities (the 'Commodities') for agreed amount. The client offers to purchase the Commodities from the Bank on a deferred payment basis. ... The client...appoints an agent (a subsidiary of the Bank), under an Agency Agreement, to sell the Commodities to a broker on behalf of the client, once the client has bought the commodities. .... The Product will be used only if other Shariah compliant modes of finance are not available in the Kingdom of Bahrain. As Shariah teachings discourage taking of debt, the clients are advised that the Product should only be used to meet the genuine need of cash for permissible use. (Shariah Pronouncement for Commodity Murabahah - Islamic Financial Institution Bahrain)

The above Shariah pronouncement is one of the examples of commodity trading by IFIs. It is structured similarly to a loan, where the counterparties are not seriously looking to buy the commodity. It is simply a mechanism through which cash is paid, and ultimately repaid at a higher value. It operates as a camouflage for debt based transactions, which makes IFIs products identical to competing conventional products and services (Chong \& Liu, 2009; Kamla, 2009; Mills \& Presley, 1999; Wilson, 2011).

We consider tawarruq (sales and buy back contract) as a non-permissible contract, as it represents a tweak of the exchange contract. Most scholars in different countries disagree with its structure. However, the report that comes to us, including from the Accounting Standard Board, shows that the bank could not 'move and fly' without this contract. At the end we allow the contract to be offered based on the increasing needs with strict requirements. We are taking the middle position, we did not give full permission and we did not prohibit it. It is permitted with very strict requirements. (SB1 -ID)

Accounting information mediates the way financial products are labeled and commodified to minimize risks and maximize profits in financial offerings, as shows in Figure 1 below. In this way PLS contracts can be combined them with alternative fixed returns contracts. The PLS schemes are 
fabricated through a hybrid combination with a loan type of contract (qard) or a negotiable Islamic debt certificate, as represented in the following guidelines for IFIs balance sheets in Malaysia.

Figure 1 Excerpt of Balance Sheet Format - (IFIs Financial Reporting - Malaysia)

\begin{tabular}{|lc|}
\hline Deposits from customers & $20 X X$ \\
Savings deposit & $R M M^{\prime} 000$ \\
Wadiah & \\
Qard & $x x x$ \\
Mudarabah & $x x x$ \\
Hybrid (Wadiah and Mudarabah) & $x x x$ \\
Demand deposit & $x x x$ \\
Wadiah & \\
Qard & $x x x$ \\
Mudarabah & $x x x$ \\
Hybrid (Qard and Mudarabah) & $x x x$ \\
Term deposit & $x x x$ \\
Commodity Murabahah & \\
Negotiable Islamic Debt Certificate (NIDC) & $x x x$ \\
$\quad$ Mudarabah & $x x x$ \\
\hline
\end{tabular}

The combination of PLS and custodianship/agency contracts (hybrid wadiah and mudharabah) require IFIs to take on-board customers PLS based deposits as a loan (qard). The depositor is deemed as a lender, which requires IFIs as borrower to return the precise amount of the PLS investment/deposit when required. Negotiable Islamic debt certificates represent debt issued by IFIs, which includes negotiation on timing of issuance and period. These instruments offer fixed returns over the entire tenure of the investment. Using accounting, IFIs structure and label all agreed contracts to provide guaranteed or fixed returns as described in the following guideline.

Types of Islamic deposits (e.g. savings, demand and term deposits) and further breakdown by Shariah contracts (e.g. Wadiah, Qard, Murabahah and hybrid.... For hybrid products, a licensed person shall disclose the applicable contracts.... Hybrid contracts are identified as those Islamic deposit products, which combine the application of two or more Shariah contracts that pose differing loss bearing risk to the customer e.g. Wadiah (custodianship) and Mudharabah (loss bearing). (Bank Negara Malaysia Guidelines for IFls Financial Reporting - issued 28 June 2013)

Such types of spiritual commodification occur when spiritual beliefs are seen as part of organizational products/services portfolios (McGuire, 2009; Moore, 2002). IFls establish a spiritual re interpretation, which represents spiritual wisdom on the modified instruments that perfectly fit with the acceptable practice. In one view IFIs may be seen to reinvigorate contemporary spirituality from the oppressive bonds of traditional religious forms. Spiritual reinterpretations become something expanded in response to the prospect of mutually beneficial contracting instruments, where parties are free to accept or reject the original religious ideals. We see this as being represented in this advisors statement. 
So far Islamic finance has probably been more successful in offering an alternative perspective on finance than in providing a substantively different way of financing. The emphasis of its theory on social consciousness, risk-sharing, redistribution of wealth and opportunity, and making finance the servant and not the master of the real economy are what many observers want to hear. But Islamic finance has found it hard to put theory into practice. Why? The list of reasons ranges from history, law, politics, regulation, taxation, consumer behavior, and beyond. But an important reason is that Islamic finance is generally made to fit into a system designed for conventional finance, and in the process of making concessions, it seems to lose what its critics regard as its substance. (AD1 - MY)

In line with this statement and our analysis above, El-Gamal (2006, pp. 148-149) defines such commodification of PLS schemes as 'Shariah arbitrage', in which IFIs seem to forbid debt-based transactions, but then permits it in modified form. Using accounting practices, IFIs argue that the typical PLS based balance sheet contains inherent risks related to such quasi-liability products (IAH or other forms of PLS deposits), which could threaten their financial security (Van Greuning \& Iqbal, 2008). These concerns over the reported financial and investment risk have been used defend the reinterpretation of alternative financial instruments that IFIs would normally offer.

IFIs argue that in order to provide alternative finance, the stability of financial position and mitigation of investments risk is a key strategy for the business. IFIs further engage in a more flexible development of hybrid products including deposit and debt-based financial instruments (represented in the proforma balance sheet, Figure 1). The commodification becomes a practical solution that uses legal devices to restructure interest-bearing debt in the form of rent or sales with mark-up transactions that combine 'interest free' certification (El-Gamal, 2007). In this process the religious rules are translated and modified in response to internal and external pressures.

It is the solution that's provided today. Everybody is happy with it. Unfortunately it is a closed box, and we found commodity sales with paper-backed transactions. But you cannot have the industry without any solutions for now. The alternative is a transparent commodity paid paper... If you really want to challenge us for that, you can't find any alternatives...(RG1 - BH in an Islamic finance global conference)

The narrative above shows how fixed income and profit and risk sharing become translations of one another. They transform PLS schemes into a totally different structure that they previously aimed to avoid. The current PLS schemes shares similar structure to debt-based financing. Accounting mediates the adjustment of Shariah principles governing PLS to suit the industry and market appetite. The nature of accounting inscription as mobile, stable, and combinable enables IFIs to modify the original PLS products (Qu \& Cooper, 2011; Robson, 1992). Accounting allows PLS contracts to be modified and appropriated into hybrid and debt-based instruments. 
... The issue of how Shariah can support the development of equity-based financing is an issue that affects the growth of the industry. We have been very much biased toward debt-based financing, which is compliant by any standard. (AD1 - OM)

Overall, accounting mediates IFIs to resolve struggles to maintain, at least the semblance of, PLS schemes. The pseudo PLS schemes allow IFIs to fabricate and commodify accounting techniques/tools that suits both market and regulatory logics. From a regulatory perspective, Archer and Karim (2009) explore similar changes of PLS in various countries. The sound of avoiding interest echoing from the religious imperative seems to be slowly disappearing as the IFIs have justified a fixed return that represents an interest based transaction as a new alternative, as represented in the following statement. In the UK, there is no specific accounting regulation in relation to income smoothing for PLS schemes. However, the regulator requires IFIs to classify PLS investment accounts into contractually 'capital certain', which requires IFIs to guarantee the investments using financial services compensation schemes. These practices show the dual role of accounting in both creating and resolving struggles in PLS practices wherever they clash with the regulatory and market logics.

In Malaysia, Bahrain and Abu Dhabi, the regulatory bodies and the industry supervisor require IFIs to manage unrestricted PLS in such a way as to avoid passing losses onto the capital providers/investors, and also to stabilise the periodic returns paid to them. The use of accounting to mediate pseudo spiritual financial products/services is partly supported by those religious scholars who are sympathetic to the expansion of IFls. Accounting enables translation and modification of the meaning of spiritual rules around PLS. The role of accounting in the commodification of religious ideals and fabrication of 'acceptable' financial products mediates interactions with the modern banking environment and provides PLS schemes to match market appetite.

\section{Discussion}

Our paper explores the infusion of religion or spiritual beliefs in IFIs as part modern financial institutions. IFIs engage in pseudo spiritual finance by selectively recontextualising the Islamic financial schemes and appropriating the substance of religious prescription. In practice, the religious rules guiding PLS schemes clashes with the characteristic of the modern capitalist ethos. To resolve the struggles IFIs engage in modifications of the spiritual framework effectively, in instances such as PLS products, mirroring its conventional counterpart. Based on the findings of this research, we extend the discussion of the role of accounting as a mediator of conflicting interests and intentions in infusing spirituality in modern organization. We reconsider how accounting mediates the tensions created by the search for spiritual perfection, and how accounting practices create a space for the mediation of conflicting interests and intentions in the following sections. 


\subsection{Accounting in-tension in the search for spiritual perfection: mediating the reinvention of}

\section{pseudo spirituality}

We argue that accounting plays a role in mediating the struggle to perfect the infusion of spirituality into modern organizations. We provide a more nuanced perspective on the complexity of this relationship within our research setting (Hardy \& Ballis, 2005) by showing how accounting works to reinvent pseudo spiritual finance as a new vision of spiritual perfection. We also provide insight on how accounting mediates the innovative adaptation of spirituality to overcome tensions between the spiritual ethos and the capitalistic hegemony of modern banking and finance (Miller \& Power, 2013; Quattrone, 2015a). Our findings show the use of accounting in enabling spiritual appropriation in the crafting of modern financial instruments.

Accounting is used to resolve struggles in the clashes that we elucidate between IFI ontotheology and the epistemology of modern banking and finance. The latter context is dominated by debt-based financing and there is much less interest in the equity-based and profit and risks sharing instruments more commonly associated with Islamic finance (Maurer, 2002; Rethel, 2010). The findings of our research provide insight by exploring how secular-rational aspects of accounting may sometimes support rather than threaten sacred values (Jacobs \& Walker, 2004).

We also expand the discussion on how accounting acts as an enabling and liberating contributor to religious organizations' spiritual mission (Irvine, 2005). In our case, in the search for spiritual perfection, accounting practices of income smoothing help mediate IFIs selective interpretation of the Shariah rules around PLS. Accounting acts as a mediator in the dynamic redefinition of the sacred law into instruments suited to contemporary finance. The spiritual rules are interpreted and translated to enable alternative banking and financial practices that complement or mirror complex modern banking products. In line with Maurer's (2001) argument on IFIs involvement in the politic of interpretation, using accounting,

Our research provides insight on how accounting facilitates innovation in the search of spiritual perfection in modern organizations, in our case IFIs. Accounting mediates the acts of fabrication and commodification of religious principles in the search for the perfect blending of the spiritual into the organizational setting. IFIs' engagement in pseudo spirituality, in which they organize the fabrication of PLS products using income smoothing techniques and commodification of the original products by arguing the risks involved in the PLS based balance sheet to achieve sustainability in the modern marketplace. The use of accounting enables IFIs to control the dynamic search of the sacred-secular balance in the pursuit of the organizational religious, economic and social imperatives. We show how accounting plays a role in navigating a way through a difficult competitive context where IFIs must maintain consistency in the interpretation and implementation 
of religious principles. It is through these malleable processes of reinterpretation of what constitutes the sacred-secular divide that concordance to those spiritual ideals is constituted.

\subsection{Accounting's role in providing space for the mediation of conflicting interests and intentions}

We provide insight on how accounting helps to reveal ways in which spirituality can be managed (Miller and Power, 2013; Quattrone, 2015a) by providing space to mediate among various interests in the context of modern organizations. Our findings show how accounting operates to embrace various interests and logics in modern financial institutions. We also provide insight on the way accounting helps to resolve the tensions between an ethical spirituality and the hegemony of financial markets (Johnson, 2017) by revealing accounting interventions around PLS. Accounting provide a space of mediation where the idea of the spiritual alternative offered by IFIs to provide safety and social supports collides with a mainstream view that supports the maximization of shareholders value (Fang, 2014; Pollard \& Samers, 2013). Within the struggles, accounting enables IFIs' efforts to embrace various interests to collectively engage in spiritual modification/appropriation around IFIs retail investment instruments.

Our findings expand discussions of the way accounting works as a tool to exercise and retain control in complex organizational settings (Robbins \& Lapsley, 2015). In our case, accounting mediates the conflicting interests within the contestations that take place in the imagined landscape of IFIs versus the logics and interests embedded in the conventional banking and finance industry (Rethel, 2017). Accounting practices and techniques enable IFIs to reassert some self-control in the struggles around the development of financial instruments on the one hand and religious values on the other (Brentlinger, 2000; Collins, 2007; Tracey, 2012).

Our research also adds to the discussion in previous studies on the struggles organizations face (Duncan, Flesher, \& Stocks, 1999; Jeavons, 1993; Kuasirikun \& Constable, 2010; Odom \& Boxx, 1988; Zietlow, 1989) by showing how accounting provides space to mediate in working with multiple transcendental values. We do this by exploring the medium used to negotiate a balance between the organization's religious mission and market exigencies (Duncan et al., 1999; Odom \& Boxx, 1988). Accounting practices are used to mediate these clashes between religious principles and market ideals. Accounting to some extent constrains but also shapes IFIs choices to engage in pseudo spiritual practices as an essential part of a process of searching for an acceptable way of retaining or infusing spiritual meaning.

Accounting's role in IFls pseudo spirituality appears to be unavoidable as they seek to align various interests and competing objectives. Accounting mediates struggles in the process of searching for spiritual perfection by selectively appropriating both the spiritual realm and situated reasoning to extend a modern form of spiritual domination at a distance (Busco \& Quattrone, 2017; 
Robson, 1992). Accounting resolves the struggles by ensuring the presentation of a product that is different but still recognisable to market participants.

\section{Conclusion and Practical Implications}

This paper argues that IFIs act to organize pseudo spiritual finance practices, in which accounting is deployed in the fabrication and commodification of spirituality. The modification of spiritual referents in PLS schemes presents what seems to remain a stable set of religious prescriptions into something which is different but still the same (Quattrone, 2004) to enable the apparent retention of this form of financing. This process of repackaging spiritual beliefs through fabrication and commodification, such as in the PLS schemes, we describe earlier, is carried out to replicate conventional finance products. The spiritual ideals become a part of the corporate machine, which is utilised by the organization or market as cultural cachet for its own purposes and profit. In this way religious belief may be deprived of its validity to inscribe religious tradition (Carrette \& King, 2005).

We explore the struggles IFIs face to provide spiritual based financial alternatives represented in the PLS schemes that ideally would provide a degree of social betterment for wider society. In responding to competitive market forces IFIs engage in struggles around pseudo spiritual finance as a performative exercise in the modification or enactment of spiritual ideals. The extent to which IFIs offer a financial alternative remains an imaginary landscape in the hegemony of neoliberal economy and finance markets (Fang, 2014; Maurer, 2012; Pitluck, 2012; Rethel, 2017).

Our findings provide an insight for IFIs to reflect on how the institution constitutes the conceptions of religious principles as a spiritual ideal to fulfil the religious imperative that has inspired the formation of these alternative-banking institutions. Our observations of and discussion of the practice of interpretation and modification/appropriation of spiritual values could provide a valuable policy reference for IFIs to reflect critically on their institutional practices. These institutions should reconsider their practice in modifying existing financial products that results in the development of complex financialization/financial engineering such as swaps and derivatives. IFIs need to examine whether their products provide the ethical alternative anticipated or simply offers another way to maintain a capitalistic financial hegemony.

A limitation of our study is that we focus on the role of accounting in pseudo-spiritual practices around PLS schemes albeit across various IFIs. Future research could explore other factors and other financial products that may also rely on or influence the adoption of pseudo-spiritual practices. Research may also explore the role of accounting practices in decision making involving more complex structured investment products, such as Islamic derivatives or financial technology based instruments. A focus could be placed on how these products conform to legitimate 
religious/spiritual ideals and the dynamics within the product development process. Further

interesting research exploration around whether 'spirituality' affects accounting in a consistent way or evidence of different effects depending on the religious ideals that each type of spirituality underpins.

In line with Haigh (2006), Forslund \& Bay (2009), McGoun (1997, 2004) McGoun et.al (2003), we recognise that the difficult marriage of IFIs' spiritual aims alongside a profit objective is likely to remain problematic. In the end, the clashes of transcendental values - Islamic values and market values - provides avenues for people to implicitly and explicitly control and redefine the values that serve their chosen aims in specific circumstances. Alternative spiritual forms of financial organizing may best be envisaged as dynamic processes in the midst of complex rationalizations of power and assignment of, or competition for authority.

\section{References}

AAOIFI, A. A. O. f. I. F. I. (2010). Accounting Auditing and Governance Standards for Islamic Financial Institutions. Manama Bahrain.

Abdul-Rahman, A., \& Nor, S. M. (2016). Challenges of profit-and-loss sharing financing in Malaysian Islamic banking. University Kebangsaan Malaysia.

Abdullah, A. (2012). Does Our PLS (Profit and Loss Sharing) Paradigm Resemble Its True Concepts. Retrieved from Malaysia:

Andon, P., Baxter, J., \& Chua, W. F. (2015). Accounting for stakeholders and making accounting useful. Journal of Management Studies, 52(7), 986-1002.

Archer, S., \& Karim, R. A. A. (2009). Profit-sharing investment accounts in Islamic banks: Regulatory problems and possible solutions. Journal of Banking Regulation, 10(4), 300-306.

Ashforth, B. E., \& Pratt, M. G. (2003). Institutionalized spirituality. Handbook of workplace spirituality and organizational performance, 93-107.

Atmeh, M. A., \& Ramadan, A. H. (2012). A critique on accounting for the mudarabah contract. Journal of Islamic Accounting and Business Research, 3(1), 7-19.

Avgerou, C., \& McGrath, K. (2007). Power, rationality, and the art of living through socio-technical change. MIS quarterly, 295-315.

Badrinarayanan, V., \& Madhavaram, S. (2008). Workplace spirituality and the selling organization: A conceptual framework and research propositions. Journal of Personal Selling \& Sales Management, 28(4), 421-434.

Bigoni, M., Deidda Gagliardo, E., \& Funnell, W. (2013). Rethinking the sacred and secular divide: Accounting and accountability practices in the Diocese of Ferrara (1431-1457). Accounting, Auditing \& Accountability Journal, 26(4), 567-594.

Bigoni, M., \& Funnell, W. (2015). Ancestors of governmentality: Accounting and pastoral power in the 15th century. Critical Perspectives on Accounting, 27, 160-176.

Board, I. F. S. (2016). Islamic Financial Service Industry Stability Report. Retrieved from

Booth, P. (1993). Accounting in churches: a research framework and agenda. Accounting, Auditing \& Accountability Journal, 6(4).

Booth, P. (1995). Management Control in a Voluntary Organization: Accounting and Accountants in Organizational Context: Garland Pub.

Brentlinger, J. (2000). Revolutionizing spirituality: Reflections on Marxism and religion. Science \& Society, 171-193. 
Busco, C., \& Quattrone, P. (2015). Exploring how the balanced scorecard engages and unfolds: Articulating the visual power of accounting inscriptions. Contemporary Accounting Research, 32(3), 1236-1262.

Busco, C., \& Quattrone, P. (2017). In Search of the "Perfect One": How accounting as a maieutic machine sustains inventions through generative 'in-tensions'. Management Accounting Research.

Callon, M. (1984). Some elements of a sociology of translation: domestication of the scallops and the fishermen of St Brieuc Bay. The Sociological Review, 32(1_suppl), 196-233.

Carmona, S., \& Ezzamel, M. (2006). Accounting and religion: a historical perspective. Accounting History, 11(2), 117-127.

Carrette, J. R., \& King, R. (2005). Selling spirituality: The silent takeover of religion: Psychology Press.

Carroll, J. E. (2012). Sustainability and Spirituality: State University of New York Press.

Cassell, C., \& Lee, B. (2017). Understanding Translation Work: The evolving interpretation of a trade union idea. Organization Studies, 38(8), 1085-1106.

Chenhall, R. H., Hall, M., \& Smith, D. (2013). Performance measurement, modes of evaluation and the development of compromising accounts. Accounting, Organizations and Society, 38(4), 268-287.

Chong, B. S., \& Liu, M.-H. (2009). Islamic banking: interest-free or interest-based? Pacific-Basin Finance Journal, 17(1), 125-144.

Chua, W. F. (1995). Experts, networks and inscriptions in the fabrication of accounting images: a story of the representation of three public hospitals. Accounting, Organizations and Society, 20(2), 111-145.

Collins, R. (2007). The classical tradition in sociology of religion. Beckford, J. e Demmerath III. NJ (Orgs.) The Sage Handbook of the Sociology of Religion. London: Sage, 19-38.

Cordery, C. (2006). Hallowed treasures: sacred, secular and the Wesleyan Methodists in New Zealand, 1819-1840. Accounting History, 11(2), 199-220.

DiVanna, J. A., Sreih, A., \& Ainley, M. (2009). A new financial dawn: The rise of Islamic finance: Leonardo and Francis Press.

Diwany, T. E. (Ed.) (2010). Islamic Banking and Finance: What It Is and What It Could Be. Bolton, United Kingdom: 1st Ethical Charitable Trust.

Duncan, J. B., Flesher, D. L., \& Stocks, M. H. (1999). Internal control systems in US churches: An examination of the effects of church size and denomination on systems of internal control. Accounting, Auditing \& Accountability Journal, 12(2), 142-164.

El-Gamal, M. A. (2006). Islamic finance: Law, economics, and practice: Cambridge University Press.

El-Gamal, M. A. (2007). Incoherence of contract-based Islamic financial jurisprudence in the age of financial engineering. Wis. Int'I LJ, 25, 605.

Ezzamel, M. (2005). Accounting for the activities of funerary temples: the intertwining of the sacred and the profane. Accounting and business research, 35(1), 29-51.

Fang, E. S. (2014). Islamic finance in global markets: Materialism, ideas and the construction of financial knowledge. Review of International Political Economy, 21(6), 1170-1202.

Forslund, D., \& Bay, T. (2009). The eve of critical finance studies. ephemera: Theory and Politics in Organization, 9(4), 285-299.

Foucault, M. (1982). The subject and power. Critical inquiry, 8(4), 777-795.

Fromm, E. (1947). Man For Himself New York: Rinehart \& Company. 1959.

Fromm, E. (1955). The Sane Society. New York: Holt, Rinehart and Winston: Inc.

Fromm, E. (1976). To Have Or to Be?(World Perspectives Vol. 50, planned and edited by Ruth Nanda Anshen), London (Jonathan Cape) 1978.

Hafeez, D., \& Muhammad, M. (2016). An Analysis of Corporate Entity and Limited Liability in Islamic and Western Perspectives of Corporate Governance. Browser Download This Paper.

Haigh, M. (2006). Social investment: subjectivism, sublation and the moral elevation of success. Critical Perspectives on Accounting, 17(8), 989-1005.

Halsall, R., \& Brown, M. (2013). Askēsis and organizational culture. Organization, 20(2), 233-255. 
Hardy, L., \& Ballis, H. (2005). Does one size fit all? The sacred and secular divide revisited with insights from Niebuhr's typology of social action. Accounting, Auditing \& Accountability Journal, 18(2), 238-254.

Hasanuzzaman, S. (1989). Limited Liability of Shareholders: An Islamic Perspective. Islamic Studies, 28(4), 353-361.

Herda, D. N., Reed, S. A., \& Bowlin, W. F. (2013). The relationship between religious beliefs and the accounting and economic practices of a society: Evidence from the Dead Sea Scrolls. Accounting Historians Journal, 40(2), 115-143.

Iqbal, \& Mirakhor. (2007). An introduction to Islamic finance: theory and practice: John Wiley \& Sons (Asia).

Iqbal, M., \& Molyneux, P. (2016). Thirty years of Islamic banking: History, performance and prospects: Springer.

Irvine, H. (2005). Balancing money and mission in a local church budget. Accounting, Auditing \& Accountability Journal, 18(2), 211-237.

Jacobs, K. (2005). The sacred and the secular: examining the role of accounting in the religious context. Accounting, Auditing \& Accountability Journal, 18(2), 189-210.

Jacobs, K., \& Walker, S. P. (2004). Accounting and accountability in the lona Community. Accounting, Auditing \& Accountability Journal, 17(3), 361-381.

Jeavons, T. (1993). The role of values: Management in religious organizations. Governing, leading, and managing nonprofit organizations: New insights from research and practice, 52-76.

Johnson, C. (2017). Commerce and Consumption The Oxford Handbook of the Protestant Reformations: Oxford University Press.

Kamla, R. (2009). Critical insights into contemporary Islamic accounting. Critical Perspectives on Accounting, 20(8), 921-932.

Knorr-Cetina, K. (1981). The manufacture of knowledge: An essay on the constructivist and contextual nature of science: Elsevier.

Kuasirikun, N., \& Constable, P. (2010). The cosmology of accounting in mid 19th-century Thailand. Accounting, Organizations and Society, 35(6), 596-627.

Latour, B. (1986). The powers of association. In J. Law (Ed.), Power, action and belief: a new sociology of knowledge? Routledge and Kegan Paul.

Latour, B. (1993). Messenger talks. Institute of Economic Research. Retrieved from

Latour, B. (1999a). From fabrication to reality. Pandora's hope. Essays on the reality of science studies.

Latour, B. (1999b). Pandora's hope: essays on the reality of science studies: Harvard University Press.

Laughlin, R. C. (1988). Accounting in its social context: An analysis of the accounting systems of the Church of England. Accounting, Auditing \& Accountability Journal, 1(2), 19-42.

Laughlin, R. C. (1990). A model of financial accountability and the Church of England. Financial accountability \& management, 6(2), 93-114.

Leardini, C., \& Rossi, G. (2013). Accounting and power in religious institutions: Verona's Santa Maria della Scala monastery in the Middle Ages. Accounting History, 18(3), 415-427.

Locke, J., \& Lowe, A. (2007). A Biography: Fabrications in the Life of an ERP Package. Organization, 14(6), 793-814.

Lowe, A. (2001). "Action at a distance": accounting inscriptions and the reporting of episodes of clinical care. Paper presented at the Accounting Forum.

Maslow, A. (1965). Self-actualization and beyond.

Maslow, A. H. (1943). A theory of human motivation. Psychological review, 50(4), 370.

Maurer, B. (2001). Engineering an Islamic future. Anthropology Today, 17(1).

Maurer, B. (2002). Anthropological and accounting knowledge in Islamic banking and finance: rethinking critical accounts. Journal of the Royal Anthropological Institute, 8(4), 645-667.

Maurer, B. (2003). Uncanny exchanges: the possibilities and failures ofmaking change'with alternative monetary forms. Environment and Planning D, 21(3), 317-340. 
Maurer, B. (2012). The Disunity of Finance: Alternative Practices to Western Finance. The Oxford Handbook of the Sociology of Finance, 413.

McGoun, E. G. (1997). Hyperreal finance. Critical Perspectives on Accounting, 8(1), 97-122.

McGoun, E. G. (2004). Form, function, and finance: architecture and finance theory. Critical Perspectives on Accounting, 15(8), 1085-1107.

McGoun, E. G., Dunkak, W. H., Bettner, M. S., \& Allen, D. E. (2003). Walt's street and Wall Street: theming, theater, and experience in finance. Critical Perspectives on Accounting, 14(6), 647661.

McGuire, T. (2009). From emotions to spirituality: "Spiritual labor" as the commodification, codification, and regulation of organizational members' spirituality. Management Communication Quarterly.

McGuire, T. (2010). From emotions to spirituality: "Spiritual labor" as the commodification, codification, and regulation of organizational members' spirituality. Management Communication Quarterly, 24(1), 74-103.

McPhail, K., Gorringe, T., \& Gray, R. (2005). Crossing the great divide: critiquing the sacred secular dichotomy in accounting research. Accounting, Auditing \& Accountability Journal, 18(2), 185188.

Meyer, J. W. (1986). Social environments and organizational accounting. Accounting, Organizations and Society, 11(4-5), 345-356.

Miller, P., \& Power, M. (2013). Accounting, Organizing, and Economizing: Connecting Accounting Research and Organization Theory. The Academy of Management Annals, 7:1, 557-605. doi:10.1080/19416520.2013.783668

Miller, W. W. (2002). Durkheim, Morals And Modernity: Taylor \& Francis.

Mills, P. S., \& Presley, J. R. (1999). The Prohibition of Interest in Western Literature Islamic Finance: Theory and Practice (pp. 101-113): Springer.

Moore, T. (2002). The soul's religion: Cultivating a profoundly spiritual way of life: HarperCollins New York.

Munro, I. (2014). Organizational ethics and Foucault's 'art of living': Lessons from social movement organizations. Organization Studies, 35(8), 1127-1148.

Nagaoka, S. (2009). Reconsidering Mudaraba Contracts in Islamic Finance: What is the Economic Wisdom (Hikma) of Partnership-based Instruments?

Neimark, M. K. (1994). Regicide revisited: Marx, Foucault and accounting. Critical Perspectives on Accounting, 5(1), 87-108.

Odom, R. Y., \& Boxx, W. R. (1988). Environment, planning processes, and organizational performance of churches. Strategic Management Journal, 9(2), 197-205.

Paisey, C., \& Paisey, N. J. (2011). Visibility, governance and social context: Financial management in the Pre-Reformation Scottish church. Accounting, Auditing \& Accountability Journal, 24(5), 587-621.

Parker, L. D. (2001). Reactive planning in a Christian Bureaucracy. Management Accounting Research, 12(3), 321-356.

Pitluck, A. Z. (2012). Islamic Banking and Finance: Alternative or Facade? The Oxford Handbook of the Sociology of Finance, 431.

Pollard, J., \& Samers, M. (2013). Governing Islamic finance: Territory, agency, and the making of cosmopolitan financial geographies. Annals of the Association of American Geographers, 103(3), 710-726.

Presser, S. B. (1992). Thwarting the Killing of the Corporation: Limited Liability, Democracy, and Economics. Nw. UL Rev., 87, 148.

Qu, S. Q., \& Cooper, D. J. (2011). The role of inscriptions in producing a balanced scorecard. Accounting, Organizations and Society, 36(6), 344-362.

Quattrone, P. (2004). Accounting for God: accounting and accountability practices in the Society of Jesus (Italy, XVI-XVII centuries). Accounting, Organizations and Society, 29(7), 647-683. 
Quattrone, P. (2015a). Governing Social Orders, Unfolding Rationality, and Jesuit Accounting Practices:A Procedural Approach to Institutional Logics. Administrative science quarterly, 60(3), 411-445. doi:10.1177/0001839215592174

Quattrone, P. (2015b). In search of what accounting is not: speculations on the future of valuing, transparency, and a new aesth-etics for governing capitalism and democracy. A Research Agenda for Management \& Organization Studies. Cheltenham: Elgar, 1-25.

Rethel, L. (2010). Whose legitimacy? Islamic finance and the global financial order. Review of International Political Economy, 18(1), 75-98. doi:10.1080/09692290902983999

Rethel, L. (2017). The imaginary landscapes of Islamic finance and the global financial crisis. Chapters, 562-579.

Rethel, L. (2018). Corporate Islam, Global Capitalism and the Performance of Economic Moralities. New Political Economy, 1-15.

Robbins, G., \& Lapsley, I. (2015). From secrecy to transparency: Accounting and the transition from religious charity to publicly-owned hospital. The British Accounting Review, 47(1), $19-32$.

Robson, K. (1992). Accounting numbers as "inscription": action at a distance and the development of accounting. Accounting, Organizations and Society, 17(7), 685-708.

Shanmugam, B., \& Perumal, V. (2005). Governance issues and Islamic banking.

Shanmugam, B., \& Zahari, Z. R. (2009). A primer on Islamic Finance.

Shapiro, B. (2009). A comparative analysis of theological and critical perspectives on emancipatory praxis through accounting. Critical Perspectives on Accounting, 20(8), 944-955.

Swanson, G., \& Gardner, J. C. (1986). The inception and evolution of financial reporting in the Protestant Episcopal Church in the United States of America. The Accounting Historians Journal, 55-63.

Thomas, A. S., Cox, S., \& Kraty, B. (2005). Structuring Islamic Finance Transactions: Euromoney Books.

Tomkins, C., \& Karim, R. A. A. (1987). The Shari'ah and Its Implications for Islamic Financial Analysis: An Opportunity to Study Interactions Among Society, Organizations, and Accounting. American Journal of Islamic Social Sciences, 4(1), 101.

Tracey, P. (2012). Religion and organization: A critical review of current trends and future directions. The Academy of Management Annals, 6(1), 87-134.

Uusmani, M. T. (2002). An introduction to Islamic finance (Vol. 20): Brill.

Valantasis, R., \& Wimbush, V. L. (2002). Asceticism: Oxford University Press.

Van Greuning, H., \& Iqbal, Z. (2008). Risk analysis for Islamic banks: World Bank Publications.

Vogel, F. E., \& Hayes, S. L. (1998). Islamic Law and Finance: Religion, Risk, and Return: Kluwer Law Internat.

Warde, I. (2010). Islamic finance in the global economy: Edinburgh University Press.

Weber, M., \& Eisenstadt, S. N. (1968). On Charisma and Institution Building: University of Chicago Press.

Wilson, R. (2011). Islamic banking and finance in North Africa: Past development and future potential.

York, M. (2001). New Age commodification and appropriation of spirituality. Journal of Contemporary Religion, 16(3), 361-372.

Zietlow, J. T. (1989). Capital and operating budgeting practices in pure nonprofit organizations. Financial accountability \& management, 5(4), 219-232. 


\section{Responses to Editor}

We are grateful that the editor provided further feedback that we found encouraging and very constructive. The comments indicated that we needed to conduct minor edit and revision of the paper.

We followed your recommendation to edit the abstract, eliminate Table 1 and maintain the narrative discussion in Section 2.

We also replaced most of our citation in our manuscript from Quattrone (2015b) into Quattrone (2015a).

The edited manuscript with track and changes is as follows:

\section{Introduction}

In contrast to modern banking and financial institutions, Islamic Financial Institutions (IFIs) were established, in part, to offer alternative to the hegemony of liberal commercial banking (Kamla, 2009) and modern Western capitalism. IFIs propose a spiritual/transcendental approach to finance that combines elements of the logics and values of the market, religion, and social welfare (Maurer, 2012; Pollard \& Samers, 2013; Rethel, 2017; Tracey, 2012). Islamic values guide IFIs to forgo speculation, excessive uncertainty in financial transactions, and what is seen as a form of injustice in the debtor-lender relationship associated with the charging of interest.

Profit-loss sharing (PLS) represents the spiritual financial transactions that avoid money creation without entrepreneurial risk (DiVanna, Sreih, \& Ainley, 2009; Diwany, 2010; Iqbal \& Mirakhor, 2007; Thomas, Cox, \& Kraty, 2005; Warde, 2010). Ideally, IFIs should promote real economic activities through equity financing and profit and PLS schemes (Diwany, 2010; Fang, 2014). PLS schemes are intended to facilitate partnership between capital providers and entrepreneurs in which they share both the risks and returns of an economic transaction. The notion of spiritual finance, such as PLS, in modern banking has been described as an imaginary landscape (Pollard \& Samers, 2013; Rethel, 2010).

In reality, IFIs operate within the context of well-established modern banking and financial markets where 'neoliberalism and market logic appear to be the only game in town' (Maurer, 2001 p.11). There is a clash between the ontotheology of IFIs and the epistemology of modern finance and banking. The PLS schemes become the imaginary landscape of IFIs and are continually subject to a 
process of ongoing negotiation and contestation (Rethel, 2017). The idea of shared risks and responsibilities in PLS schemes clashes with the strong roots of the limited liability conception of the modern corporation. These differences become an increasing pressure in the fierce competition in the markets where IFIs operate.

Our paper seeks to explore the role of accounting in IFls' practice of interpretation within the struggle these organizations face around the implementation of PLS schemes as a means of spiritual based financial alternatives. We focus on the following questions; how spirituality as a basis of alternative form of financial organizing is translated within organizational settings and how accounting is implicated in this process? What role(s), if any, does accounting play in rendering notions of religious/spiritual values applicable to practice or how it colludes against their implementation?

We provide an examination of the deeper nuances of the intersections between religion and accounting (Hardy \& Ballis, 2005; Jacobs, 2005; Shapiro, 2009) by exploring the role of accounting in responding to the tensions created by the infusion of spirituality into modern organization, such as IFIs. Our paper contributes to the literature on the mediating role accounting plays in addressing or revealing 'intentio (the end)' (Miller \& Power, 2013; Quattrone, 2015a) by showing how accounting resolves the struggles between the sacred/religious ontotheology and the secular capitalistic epistemology of modern banking. We provide insight on how accounting works to manage the invention and reinvention of spirituality in modern financial institutions by creating pseudo spiritual financial products. This involves mediation among various interests and intentions to foster the innovative adaptation of spirituality.

IFIs use accounting in a fabrication, and commodification of the original PLS schemes. In our case, spirituality and accounting are combined in the negotiation of a balance between the religious/spiritual ideals and the situational requirements of product design/legitimation. Our study suggests that IFIs should reflect on the modification/appropriation of PLS schemes that induce complex financial engineering, and whether those financial products in the end provide an alternative or just another incarnation of capitalistic financial hegemony.

The remainder of this paper is structured as follows. Firstly, we offer our perspective based on a range of literature and ongoing debate around accounting and religion, the struggle to modify PLS schemes, and how accounting is engaged in organizing pseudo spirituality. Secondly, we outline the approach to data collection, our interpretivist approach to analysis, and the research context. In the following sections, we explore the way IFIs engage in the creation of pseudo spiritual finance to encourage, but also to mimic, transcendence with the spiritual ideal. We complete the paper with conceptual and practical insights in the discussion and conclusion section. 


\section{Accounting and Religion: Investigations of sacred and secular dichotomies}

Accounting research has partly explored the interaction between accounting practices and religion (Booth, 1993; Carmona \& Ezzamel, 2006; Jacobs, 2005; Laughlin, 1988; Quattrone, 2004). The sacred sense of human stewardship is incorporated in everyday accounting and budgeting practices (Irvine, 2005). It represents the accountability of material resources given by God (Jacobs \& Walker, 2004), and the guardianship role of accountants in the control of financial affairs (Jacobs, 2005; Parker, 2001; Quattrone, 2004).

Much of this research has been focused on the function of accounting within religious institutional contexts. Accounting plays an important part in controlling the theology and spirituality of many religious institutions, such as the lona community (Jacobs \& Walker, 2004), the Protestant Episcopal Church in the USA (Swanson \& Gardner, 1986), the Australian Uniting Church (Booth, 1993), and the Society of Jesus (Quattrone, 2004). The impact religious/spiritual values in the sociocultural and historical context of societies and organizations can be separated into two main streams of research.

One stream of research that examined the sacred and the secular (the profane) dichotomy became a dominant interpretive model for examining the situated accounting practices of religious organizations. This lens became influential following the seminal works of Laughlin $(1988,1990)$, Booth (1993, 1995), Faircloth (1988) and Swanson \& Gardner (1986). These studies focused mainly on the contrasting features of what was perceived as the secular function of accounting with the sacred objectives of religious organizations. They are premised on a clear separation of the boundaries of sacred and secular activities. Religious organizations are seen to buffer the sacred from worldly concerns as they attach religious meanings to secular activities.

The other stream, however, views sacred and secular as a continuum and inseparable in the complex environment of religious organizations (Hardy \& Ballis, 2005; Irvine, 2005). Those studies do not support the idea that religious organizations' sustainability is dependent on the effectiveness in facing pressures to change and the ability to slow down the intrusion of the secular. Accounting is not seen as a threat to the sacred values in some religious organizations (Jacobs \& Walker, 2004). It is these views of the blurring of boundaries between the sacred and secular that offer a useful lens into how non-religious activities, such as accounting, can be used to facilitate spiritual belief and practices of religious organizations.

The second research stream argues that sacred and secular imperatives are integrated or blended in religious organizations. This presents a more unified perspective on spirituality, where the sacred and the secular are constantly being redefined. Accounting is used in a pragmatic within the theological differences (McPhail et al., 2005) that enable alignment with the organizations' spiritual mission (Irvine, 2005), to retain control in the complex setting of religious organizations (Robbins \& 
Lapsley, 2015). Those studies, however, mainly focus on religious organizations or spiritual communities (Cordery, 2015).

With the increasing attention to spirituality in modern organizations, Tracey (2012, p. 119) calls for the exploration of how modern organizations employ spiritual/religious values. The extent to which accounting is implicated within the sacred-secular epistemological clashes can provide interesting insights. Such inquiry would further the discussion on the role of accounting as mediator in the tensions of submission to spiritual values but also to the stringencies of an economic perspective, as discussed in the following section.

\section{Accounting In-tension: Reinventing Spirituality to Mediate Conflicting Interests}

Foucault (1982, p. 331) argues that organizations experience the 'struggle against subjection, against forms of subjectivity and submission', which represents the difficulties in tying their own identity to organizational spiritual ideals. Spiritual ontotheology meets and clashes with the epistemology of modern organizations (Rethel, 2018). Spiritual/religious ideals in modern/secular organization have been said to be always 'in-tension' (Busco \& Quattrone, 2017). These tensions can be illustrated in the appropriation of spiritual ideals by secular organizations. Organizations seek to deconstruct religious ideals to create identifiable knowledge claims and moral guidelines to inform organizational actions.

This requires a continuous search for spiritual perfection, where religious guidelines are constantly classified, scrutinized, and reinvented to enable their implementation/reimplementation. 'Without this intentio (the end), there is no inventio (the means) and thus no rationes, no inventory, no invention, and no divine truth' (Quattrone, 2015a, p. 11) - the translation of religious rules within organizational activities requires continuous adaptation to suit different situations, logics and interests. The perfect translation of religious/spiritual ideals is somewhat left ambiguous as it needs to provide room for further pragmatic classification and reclassification. An adaptable spiritual purpose is required in order to embrace the various interests and intentions of organizational actors.

Collective effort in mediating conflicting interests is critical to the reinvention of a new mutual vision of spirituality in the modern organization. To embrace various interests, accounting plays a role in mediating practice, by creating a common narrative that bridges the various interests of different actors within the internal and external network of relations of the enterprise (Miller \& Power, 2013). Accounting plays a role as a mediating instrument of hegemonic domination of modern capitalism, serving as an engine of efficiency (Neimark, 1994; Quattrone, 2015b). Within the struggles of fitting spirituality into the capitalistic logic of modern organizations, accounting acts 'to count, not the visible, but the invisible' (Meyer, 1986, p. 351). Accounting in this case is used to 
interrogate the invisible nature of spiritual ideals to make it compatible with organizational interests. Using accounting, organizations craft and reinvent the spiritual rules (Quattrone, 2015a) to align the competing sacred and secular objectives with which they are faced.

Accounting practices enable the assemblage of various components with different ontologies, ideas and routines embedded in the religious/spiritual ideals and secular/commercial interests. It mediates clashes between theological and commercial logics. In the Renaissance period the calculation of interests was disguised in financial instruments such as bills of exchange in a way that differentiated it from usury may the across (Johnson, 2017). Accounting is implicated in a fertile arena for productive debate, mediation, compromise and innovative interrogation of what constitute the acceptable spiritual ideals in organizations. Accounting helps to speculate how spirituality could be managed in a way to link the interests of various actors within and beyond the boundaries of organizations (Chenhall, Hall, \& Smith, 2013; Quattrone, 2015a). Accounting, in this context of flux and incompleteness, is employed by actors to question what constitute spiritual infusion in modern organizational practices and facilitate an iterative and innovative search for spiritual perfection (Busco \& Quattrone, 2017).

Accounting mediates the need for organizations to negotiate complex interests by offering 'pseudo religious' or 'pseudo spirituality' - innovative and adaptable spiritual ideals (Carroll, 2012; Halsall \& Brown, 2013) through which selectively reasoned spiritual stances or attitudes are reinvented (Avgerou \& McGrath, 2007). Accounting is both agent and outcome, both idea and practice to create greater autonomy in merging the religious/spiritual and secular/commercial arenas. Accounting serves a purpose in mediating the spiritual struggles due to its ability (through inscription) to be made mobile, stable, and combinable (Qu \& Cooper, 2011; Robson, 1992). The textual and graphical creativity of accounting inscriptions are influential in constructing the appropriatly persuasive spiritual practices, in order to articulate compliance with the pre-existing hegemony while infusing the religious ideals.

In the continuous reinvention of pseudo spirituality, the fabrication of accounting tools and techniques serves the purpose to mediate and reproduce the new spiritual vision that is accepted by various actors with different interests and logic in the modern organization. Fabrication represents processes that strengthen and stabilise accounting information as a fact-like but imperfect creation (Chua, 1995; Latour, 1999a; Locke \& Lowe, 2007). The fabrication of accounting tools involves chains of selection, translation and appropriation of spirituality to achieve acceptable pseudo-spiritual practices (Knorr-Cetina, 1981). The mediating role of accounting is temporary, and might change according to situational needs and interests, which includes reinventing spiritual beliefs as part of the products an organization offers (McGuire, 2009). Accounting mediates the act of 'commodification of religion', through which organizations leverage the labels/claims of religious authenticity (Carrette \& 
King, 2005). The mediating role of accounting is more of a permanent process than a stable outcome as part of maintaining spiritual legitimacy 'in-tension' within the ever-changing composition of organizational spiritual visions.

\section{Research Design}

\subsection{Data collection}

This study adopts a qualitative research methodology, consisting of interviews and observation on industry players' discussions/forums supported by extensive documentary analysis from leading IFIs. Qualitative methods enables us to offer a detailed illustration of the mechanisms and practices at work that provide insights into the ways in which accounting mediates the translation or modification of the original concept of profit and loss sharing (PLS) scheme into financial instruments/products in IFIs. Our data is draws from IFIs across 6 countries, including Malaysia, Indonesia, Abu Dhabi, Bahrain, Oman and the United Kingdom. We describe how and why accounting, is implicated in the reinvention and innovative interrogation of the central tenets of PLS schemes in the modern banking products. The qualitative methods adopted were crucial in enabling us to explore how and why accounting can mediate the appropriation and mutual translation of what constitutes the spiritual perfection of PLS instruments by creating 'acceptable' but spiritually dubious PLS instruments.

We collect data from interviews, documents including regulatory frameworks, and observations on industry discussions/forums related to PLS instruments. We conducted interviews with 40 participants from Indonesia, Malaysia, Bahrain, Abu Dhabi, Oman and the United Kingdom (UK), as shown in Table 1 below. We recorded the interviews, which ranged between 45 minutes to 2 hours. The interview participants included 17 IFIs managers, 4 national and global advisors, 7 Shariah compliance officers, 6 Shariah supervisory board members and 6 leading managers of national and international regulatory bodies. We selected participants who have 10 to 20 years working experience in the leading and/or pioneer Islamic banks and regulatory bodies that involve in the implementation of PLS schemes.

Table 1 Interviewees detail

\begin{tabular}{|lccccccc|}
\hline Countries & $\begin{array}{c}\text { Indonesia } \\
\text { (ID) }\end{array}$ & $\begin{array}{c}\text { Malaysia } \\
\text { (MY) }\end{array}$ & $\begin{array}{c}\text { Bahrain } \\
\text { (BH) }\end{array}$ & $\begin{array}{c}\text { Abu Dhabi } \\
\text { (AD) }\end{array}$ & $\begin{array}{c}\text { Oman } \\
\text { (OM) }\end{array}$ & $\begin{array}{c}\text { United } \\
\text { Kingdom (UK) }\end{array}$ & Total \\
\hline Manager (MG) & 6 & 2 & 2 & 1 & 1 & 5 & $\mathbf{1 7}$ \\
\hline Adviser (AD) & 0 & 1 & 1 & 0 & 1 & 1 & $\mathbf{4}$ \\
\hline $\begin{array}{l}\text { Shariah Compliance } \\
\text { (SC) }\end{array}$ & 3 & 1 & 1 & 0 & 1 & 2 & $\mathbf{7}$ \\
\hline Shariah Board (SB) & 1 & 1 & 1 & 1 & 0 & 2 & $\mathbf{6}$ \\
\hline Regulator (RG) & 2 & 2 & 1 & 0 & 0 & 1 & $\mathbf{6}$ \\
\hline Total & $\mathbf{1 1}$ & $\mathbf{7}$ & $\mathbf{6}$ & $\mathbf{2}$ & $\mathbf{3}$ & $\mathbf{1 1}$ & $\mathbf{4 0}$ \\
\hline
\end{tabular}


Our interviewees come from different socio-political environments and different institutional settings reflecting various economic histories and developmental experiences. However, our intention was not to compare such differences or how they may influence the orientations of the individuals. We sought to explore their experiences of the processes of translation and/or reinvention of the original PLS schemes into the contemporary IFIs PLS instruments. We look more into the way IFIs translate the PLS concept in the design of PLS based financial instruments. Our interest is in how the translation occurs (Cassell \& Lee, 2017; Latour, 1993), which implies the adjustment, displacement, rationalisation, reinvention, mediation, and recreation/repackaging of PLS products/instruments.

We have sought to explore the interviewees' experience in the process of translation, during their involvement in modifying, moulding and contextualising the religious/spiritual ideals that governed the original PLS schemes to suit the competing demands present in the contemporary financial environment. We explore what is represented in the translation of PLS schemes, and how accounting is implicated. In line with Callon (1984), we view translation as a process rather than a result. We concentrated on the acts within the translation process, and demonstrate how cumulatively they have changed the character of PLS instruments and re-configure power and knowledge relations within the field of Islamic finance (Cassell \& Lee, 2017). We have sought to identify the way actors interpret the PLS schemes and how they made us of translation processes as an energy that enables movement (Latour, 1986, p. 267). The interviews were typically centred around three main themes: (1) the spiritual ideals of PLS schemes and the issues, challenges and tensions in implementing the original PLS schemes (2) their interpretation of Shariah/spiritual ideals in contemporary PLS schemes, (3), the rationalisation, modification, and adjustment processes which occur as Shariah compliance principles are applied in the PLS instruments, and (3) the arguments/rationales behind new forms of PLS schemes.

Table 2 Documentary Data

\begin{tabular}{|lll|}
\hline \multicolumn{1}{|c|}{ Type } & \multicolumn{1}{c|}{ Title } & \multicolumn{1}{c|}{ Related Information } \\
\cline { 2 - 3 } IFIs documents & Shariah pronouncements on PLS & $6 \mathrm{IFIs}$ \\
\cline { 2 - 3 } & Accounting guidelines on PLS & $6 \mathrm{IFIs}$ \\
\cline { 2 - 3 } & Product documentations on PLS & $6 \mathrm{IFIs}$ \\
\cline { 2 - 3 } & Financial reporting & $6 \mathrm{IFIs}$ \\
\hline Regulatory Framework & Shariah Standard on PLS & $\begin{array}{l}\text { AAOIFI and National Shariah standards } \\
\text { (Indonesia, Malaysia, Oman) }\end{array}$ \\
\hline & Central bank guidelines on PLS & Central banks of all 6 countries \\
\hline & Accounting standards/guidelines & $\begin{array}{l}\text { AAOIFI and National Islamic accounting } \\
\text { standards/guidelines of all 6 countries }\end{array}$ \\
\hline
\end{tabular}


We also collected documents related to PLS instruments from six IFIs offering commercial banking services in each of the six countries, as listed in Table 2 above. We explored the translations of PLS products, by examining IFIs' documents, such as Shariah pronouncements, product documentation, accounting guidelines, and financial reporting related to PLS instruments. We also explored the regulatory framework and accounting standards/guidelines on PLS instruments produced by central banks in the six countries and the international accounting standard setting body, Accounting and Auditing Organization for Islamic Financial Institutions (AAOIFI).

In addition, we carried out observations of industry discussions and debates on PLS instruments. We personally attended and observed two annual global Islamic finance conferences, one in Indonesia and one in the UK. We also observed several roundtable discussions and a Shariah scholars' forum on PLS instruments held by the regulators and the global network of IFIs in each of the selected countries. Those forums involved discussions among Islamic banking executives, Shariah scholars, and global Islamic finance regulators. Those forums provided a setting in which we could observe the views on the design and implementation of PLS schemes, the development of Shariah opinions along with updates on recently introduced PLS products/instruments. Finally we also explored various regulatory and accounting standards and IFIs reporting on PLS schemes in the each of the chosen countries.

\subsection{Data analysis}

We transcribed and analysed the interviews using NVivo 9.2 qualitative data analysis software. We use NVivo for both data management and the early coding process of the interviews, which allows line-by-line coding of data. We carried out a thematic analysis of the narratives in our interview and documentary data. This is discussed in the following steps.

Step 1: Identifying empirical themes. The first step involved the development of first-order codes, in which the 40 interviews and documentary data were coded with NVivo 9.2 using thematic content analysis. This process enabled us to identify and extract the themes that were recurrent in the interviewees' accounts. The analysis was then strengthened by a further manual review of the codes, which at many points enable us to construct additional codes. The rationale behind the combination is to enhance research effectiveness and to emphasis the central role of the researcher in the analysis process, as coding and analysis 'is not a merely technical task' and that 'no mechanism can replace the mind and creativity of the researcher' (Marshall \& Rossman, 2010, pp. 218-219). From this first level of coding, we identified several themes, such as: the role of Shariah; the importance of PLS schemes; Shariah principles governing PLS products; pressures and challenges in implementing PLS schemes; conflicting demands influencing PLS modifications; the role of accounting reserves in maintaining PLS returns; income smoothing techniques in PLS instruments; 
combination and monetization of Shariah contracts; repackaging PLS schemes and other contracts to fixing return.

Step 2: Identifying conceptual categories. We reiterated the analysis of our data giving consideration of the literature on the role of accounting in spiritual/alternative forms of financing. We compared the themes from the data with one another. We consolidated the themes in higher conceptual categories from our second order coding themes, which included: Shariah/religious principles as a spiritual ideal (first level coding: the role of Shariah, the importance of PLS schemes, Shariah principles governing PLS products); the struggles and challenges faced by IFIs to implement of the spiritual ideal (first level coding: pressures and challenges in implementing PLS schemes, conflicting demands influencing PLS translations); and fabrication of PLS instruments (first level coding: the role of accounting reserves in maintaining PLS returns, income smoothing techniques in PLS instruments); and commodification of PLS instruments (first level coding: combination and monetization of Shariah contracts, repackaging PLS schemes and other related contracts) .

Step 3: Identification of the outcome from our analysis. We identified the outcomes of our analysis, which shows how IFIs sought to implement PLS schemes within the attendant epistemological and operational struggles. We identified that the accounting for PLS schemes creates a struggle, to balance financial market requirements with Islamic religious principles, that is resolved through the appropriation and translation of the religious principles guiding the offerings of PLS products. We identified accounting role in mediating the form of pseudo spiritual finance. These processes involved the IFIs in fabrication, commodification and the use of accounting practices to engage in the translation of original PLS instruments. We base our conceptualisations on the fabrication techniques discussed in the literature to portray the use of accounting as a mediating tool which IFIs use to resolve struggles around PLS schemes by using appropriated accounting techniques to show pseudo instruments as spiritual-like or but imperfect creation (Andon, Baxter, \& Chua, 2015; Busco \& Quattrone, 2015; Chua, 1995; Knorr-Cetina, 1981; Latour, 1999a; Locke \& Lowe, 2007)

In our analysis the data revealed IFIs' engagement and mobilisation of pseudo spiritual finance that shared similar form of spiritual commodification, in which organizations seek business and profit expansions by to leverage claims of religious authenticity and to label the fabricated PLS products as marketable goods (Badrinarayanan \& Madhavaram, 2008; Carrette \& King, 2005; McGuire, 2009; York, 2001). We have sought to explore how IFls rationalise the shifts of interpretation and meaning, which we apply to explain the translation of spiritual substance in PLS contracts. In turn, we uncovered the use of accounting in creating pseudo spiritual practices to promote mechanisms to deal with the struggles that take place in the crafting and blending that lies behind the creation of modern financial instruments alongside religious ideals, as discussed in the following section. 


\section{IFIs Spirituality and the Struggle to Translate PLS Schemes}

\subsection{IFIs' religious ideals around PLS Schemes}

IFIs originate and seek to retain an identity of spirituality and religious vision (Ashforth \& Pratt, 2003; Tracey, 2012), which encompasses three primary dimensions: (1) transcendence or connection to a "higher power" than his/her self (Islamic religious belief); (2) holism and harmony or integration of one's identity/belief to the Islamic values/religious perspective; and (3) growth or the way Islamic religious or spiritual values provide a sense of self development and self-actualization. IFIs develop from the religious imperative to infuse Shariah as spiritual ideal into financial transactions and instruments. The elements of Shariah concepts are deployed in the governance of IFIs in the same way as it is intended to provide an ethical framework for individuals.

IFIs practices should be designed to avoid exploitations and injustice in the treatment of shareholders and customers alike (Bala Shanmugam \& Zahari, 2009). The religious imperative demands responsibilities of IFIs and a dedication to work to empower society through partnership and philanthropic activities (Balachandran Shanmugam \& Perumal, 2005). This idea of spiritual vision is supported from long ago in the views of Maslow $(1965 ; 1943)$ and Fromm $(1947,1955,1976)$, to resolve the ecological disasters and moral issues wrought by global industrialization, consumption and modernization. In their views, humanistic management might serve as an effective replacement for bureaucratic management and the logic of capitalist consumption that imposes constraints on the development of an authentic self.

The alternative spiritual vision could enable IFIS to engage in a form of self-examination with reference to religious reference/ideals to create social enthusiasm, which can lead the individual to self-mastery and the achievement of their desired objectives (Valantasis \& Wimbush, 2002). IFIs have acknowledged the sacred principle that they should differentiate themselves from contemporary banking and finance. The religious imperative requires IFIs to internalise religious dogma into modern financial instruments (Chapra \& Ahmed, 2002; Iqbal \& Mirakhor, 2007). IFIs' religious ideal is characterized by the awareness that god directs behavior, and in which the actor is seen as 'an instrument of god' (Weber \& Eisenstadt, 1968, p. 278). The fundamental principles of Shariah related to commerce guides IFIs to avoid interest-based activities, excessive uncertainty, and taking gain without either performing effort or accepting liability. IFIs are charged, through Shariah, to promote equally distributed returns, risks and obligations (Khir, Gupta, \& Shanmugam, 2008).

IFIs' commitment to a religious order is expected to induce a 'conscience collective', through which positive fellow-feeling, attachment, and morality imposes itself as 'a social discipline' coming, not from outside, but from within (W. W. Miller, 2002, pp. 35-36). The Islamic ruling requires business to facilitate economic transactions by eliminating vagueness or misunderstanding in all 
types of transactions having certain underlying assets. IFIs are encouraged to be involved in promoting productive and entrepreneurial activities by offering PLS schemes, a form of venture capital and partnership that shares both profits and losses/risks generated from the agreed investments, as narrated in the following religious scripts.

Spend your wealth for the cause of Allah, and be not cast by your own hands to ruin; and do good. Lo! Allah loveth the beneficent. (Qur'an: 2:195)

They were expert in business enterprise, keen and persistent in a variety of economic pursuits. They did not do so to amass wealth or save it for themselves; rather their aim was to spend their earnings in good causes. (Shatibi, Al-Muwafiqaat fi Usul alShari'ah, Vol. 2, p188, Cairo, Maktaba al Tijarah al-Kubra.)

These religious exigencies suggest that IFIs ought to engage with socio-economic development, especially in supporting entrepreneurs and partnering among businesses. The spiritual ideals ${ }^{1}$ stipulate venture investment and partnership contracts as a desired means of conducting business. PLS was meant to represent the essence of IFIs ethical financing. PLS contracts have long been offered as an alternative to debt-based financing through collaborative business that emphasizes the sharing of profits and losses in line with Islamic principles (Diwany, 2010; Warde, 2010). PLS is a contractual arrangement between two or more transacting parties, which allows them to pool their resources to invest in a project to share in profit and loss (Kamla, 2009). PLS schemes include mudharabah (a partnership between entrepreneurs (the provider(s) of labour) and capital providers. In mudharabah the partners agree how profits will be shared, and any losses to be borne by the capital providers. Alternatively in musharakah (an investment partnership, which requires each party to have capital contributions, with losses shared in proportion to the contributed capital) (Abdul-Rahman \& Nor, 2016; Diwany, 2010; Uusmani, 2002). The ideal concept of PLS schemes, however, is difficult to implement in modern banking and finance ${ }^{2}$. Accounting for PLS creates struggles for IFIs as discussed in the following sub-section.

\footnotetext{
${ }^{1}$ The interpretation of the religious rules or ljtihad in Arabic terminology is exercised through the consensus of the scholarly Muslim community (ijma), reasoning by analogy (qiyas), judicial preference (istihsan), public interest (maslaha), and custom (urf). The interpretation of Islamic law is in the form of an entanglement of both individual and institutional perspectives in introducing rulings for new cases. In order to arrive at a consensus (ijma), as one of the most powerful references in Islamic jurisprudence, each scholar within a certain Muslim scholars institution (i.e. International Islamic Fiqh Academy, the UK Islamic Sharia Council, Majelis Ulama Indonesia, Jawatankuasa Fatwa Kebangsaan Malaysia) undertakes an individual interpretation (ijtihad), and at a point in time they gather for the purpose of in-depth discussion and debate on the authenticity of texts, their meaning and implication, in order to achieve an agreement on a certain Shariah opinion (fatwa) (Diwany, 2010; Iqbal \& Mirakhor, 2007).

${ }^{2}$ Ideal PLS practices are found outside banking context in the form of venture investments. Those practices try to move away from the debt-based schemes/instruments of modern banking.
} 


\subsection{Struggles with Accounting for PLS Schemes}

IFIs' ideals and modern banking and finance have different objectives. The epistemology of contemporary banking and finance instruments militates against the ontotheology of PLS products (Maurer, 2003; Rethel, 2017). The socioeconomic and ethical objectives of PLS schemes are alien to the profit seeking and money creation practices of contemporary banking and finance. These epistemological clashes can be traced back to the development of the limited liability concept of the Joint Stock Company in the $19^{\text {th }}$ century, where the legal entity of corporation is separate from its members/shareholders (Hasanuzzaman, 1989). In 1882, the United State legislation for corporation removes the unlimited liability requirement imposed on the corporate shareholders to 'facilitate the formation of partnerships without the risks ordinarily attending them, and to encourage internal manufactures' (Bloom, 1882 in Presser, 1992, p. 155). It is believed that capital formation could be better accomplished by encouraging shareholders to invest by limiting their risks and liability. Investors do not invest to lose their initial investment. In the limited liability context, investment risks are mitigated and company liabilities cannot be imposed to its shareholders (Hafeez \& Muhammad, 2016; Presser, 1992).

In contrast, the religious (Shariah) rules around PLS schemes consider the liability of partners/investors to be unlimited. The Islamic legal maxim suggests that profits are concomitant with risks and liabilities (al kharaj bil dhaman) and any transactions/sales/trading should be based on asset ownership (Iqbal \& Mirakhor, 2007; Presser, 1992; Vogel \& Hayes, 1998). One is prohibited from selling something that they do not own, while profit should arise from the effort of the parties and from assets under their ownership. Those concepts are represented in the accounting for PLS schemes, by which the investors entrust some funds to the entrepreneurs on an agreed profitsharing basis.

Deficits/losses arising from investments at the end of a specified period are to be borne solely by the investors of the venture fund in mudharabah contract or in proportion for musharakah contract. In the case of losses, the investor will bear the losses up to the maximum value not exceeding the original capital invested. At the same time, in the case of default of a mudharabah contract, the entrepreneurs will not be entitled to any profits. This uncertainty of PLS returns, linked to the high level of risks and information asymmetry around this type of venture business, is radically different to the relative certainty of contemporary banking and finance. In the view of risk-averse investors, limited liability is an attractive element of the modern banking system.

Figure 1 Comparison of Balance Sheet Elements 
Elements of IFIs' Balance Sheet Conventional Balance Sheet

\begin{tabular}{|l|l|}
\hline Assets & Assets \\
Liabilities & Liabilities \\
Equity of IAH from PLS contracts & Owners' Equity \\
Owners' Equity & \\
\hline
\end{tabular}

On the contrary, PLS schemes require a risk taking spirit and a higher degree of monitoring and cost of operation. Accounting for PLS schemes clashes with conventional accounting concepts (Maurer, 2002). Conventional accounting's entity theory is not conducive and conflicts with the reporting of PLS schemes in the balance sheet. Under PLS schemes, IFIs regard depositors as investment account holders (IAH)/investors who contributes a certain amount of capital in return for a percentage of the profit or loss based on their deposits/investments. This requires IFIs to manage and invest IAH investments in productive enterprises. As shown in Figure 1, IAH funds cannot be considered as a liability, as IFIs are not obliged to return initial investment in the case of loss (Tomkins \& Karim, 1987). At the same time, IAH funds cannot be considered as the owners' equity, since IAH do not enjoy powers and ownership rights (Atmeh \& Ramadan, 2012). In that case, by offering PLS schemes IFIs' balance sheet should show a different feature, which makes it difficult for IFls that operate within the modern banking and finance hegemony.

From a conventional accounting perspective, subject to the separation of owners and entities, the depositor is regarded as customer who is insulated from any business decision-making (AAOIFI, 2010; Maurer, 2002). Conventional banking and finance is limited to intermediary services for depositors. In that case, savings products constitute a liability. In this context the bank is only obliged to act in the interest of shareholders. The bank obligation is limited to providing fixed interest return to customers, which require simple accounting calculations. On the contrary, PLS schemes pose income calculation issues.

PLS schemes also provide the opportunity for investors/IAH to invest their money in restricted or non-restricted types of projects. There are several accounting issues with these types of PLS investment. IFIs need to identity the entity's assets. There are confusions as to whether IFIs must measure the entity's assets based on the real value of the assets, the initial value of investments, or some other liberal approach such as investment values with inflation adjustments or projected liquidation values (Maurer, 2002). In this case, the IFIs should also carefully avoid the possibility of interest ( $r i b a$ ) element hidden/integrated in some of those methods. This creates contextualization issues from the accounting point of view, particularly on how to delimit, bound and abstract from the practice of IFIs' investment activities for IAH and IFIs' shareholders. 
PLS products also create complexity in the income recognition for IFIs when operating in the logic and hegemony of conventional banking. The agency of PLS schemes is dispersed into multiple agencies for various proprietors (IAHs and IFIs' shareholders). Income becomes disaggregated from 'temporally fixed into contemporary assessments of cash equivalencies, in a continuous and real time marking to market' (Maurer, 2002, p. 656). The accounting for PLS creates struggles to cope with the constant and indefinite valuation of assets for various shareholders and IAHs. The practical accounting complexities create tension as to whether IFIs can fulfil the imaginary dream of PLS schemes, when it cannot easily play in a market wholly demarcated from contemporary banking. Within this epistemological and contextual struggle, accounting is implicated in IFI efforts to mediate conflicting interests and resolve struggles by constructing pseudo spiritual practices as discussed in the following section.

\section{Pseudo Spiritual Finance: Organizing an Alternative Profit and Loss Sharing Contracts}

... It is difficult for banks to implement profit and risk sharing contracts because the risks are very high...especially when it is associated with operating and monitoring costs, production costs, current economic conditions, the issue of asymmetric information, adverse selection and moral hazard..." (MG1 - MY)

IFIs adherence to a spiritual agenda to provide equity-based finance through PLS schemes is found to be an on-going search and reinvention. The accounting of equal sharing of profit and loss/risk has creates struggles for IFIs as it clashes with the modern conceptions of entity theory and limited liability. In practice, market interest and logic shape the way IFIs perceive the high level of risks and the lack of capital security involved in the PLS schemes. The conflicting interests and the practical complexity in applying the original PLS schemes influences IFIs' appetite to reinvent an acceptable vision of PLS products, as narrated below.

The original dreams of Islamic finance was a double investment structure, where depositors would invest their money with the bank, and the bank would invest that money to businesses, and there would be a sharing of risks, and the profit will be shared with the depositors. But, that's not always being lived up to. There is a question whether people want that level of exposure. (AD2 - UK)

As a modern business, the primary function of IFIs is to generate as much return to shareholders as conventional banks. The economic imperative of modern banking places IFIs under pressure to increase profit year on year, to add value to shareholders' investments. At the same time, to follow the religious orders, Islamic banks cannot involve in highly leveraged risk transferring instruments as conventional banks. This requires IFIs to resolve the spiritual struggles. 
During this short span of time, IFls have succeeded in formulating many innovative risk-sharing instruments that have enabled them to compete with their conventional counterparts (MG1 - AD)

Using accounting techniques, IFIs engage in fabrication and commodification of religious orders guiding PLS schemes to reinvent a form of pseudo spiritual finance. Pseudo spiritual PLS is reconstructed in an innovative manner suitable to the modern banking systems by engaging in fabrication of accounting tools/techniques and commodification of the fabricated spiritual products, as discussed in the following two sub-sections.

\subsection{Fabrication: how accounting creates a new vision of PLS instruments}

IFIs engage in the fabrication of accounting tools and techniques to guarantee IFIs and shareholders investments. Ideally, both the bank/investors and entrepreneurs involved in the PLS transaction share any profit and potential risks resulting from the PLS venture. However, the dyadic relationship in such contracts, involves incentive problems and issues of asymmetric information between the capital provider and the entrepreneur (Nagaoka, 2009). This requires additional cost for the investor/capital provider in monitoring the efficiency of capital investment and business processes of the agent/client. Pseudo spiritual PLS enables to IFIs to ensure investors' initial capital and returns of investments are protected from the relatively high risk of venture type investments in PLS contracts/products (Abdul-Rahman \& Nor, 2016; Uusmani, 2002).

The original PLS schemes creates issues for IFIs as it contradicts conventional retail banking accounting logic, where a bank's losses are not directly passed on to depositors. The depositors' principal investments are usually preserved. Conventional banking and finance provides financial protection and indemnity from losses for individual capital providers/depositors/investors. The lack of capital protection makes IFIs products less attractive compared to their conventional counterparts. This requires IFIs to rely on the strength and stability accounting information as a fact-like but imperfect creation to help create spiritually based financial products (Chua, 1995). The fabricated reserves and income smoothing techniques that are used to guarantee the initial capital and return of investments mediate the conflicting accounting logics. IFIs have sought to find remedies to the incompatibility between religious reference and the market appetite surrounding profit and risk contracts/transactions. As discussed in the quote below, IFIs argue that the risk profile of investors/depositors be similar to that of conventional banking and finance.

Shari'ah, as authentically derived from its sources of Al-Quran, Al-Sunnah, Al-ljma' and Al-ljtihad, has ordained that both categories of contracts of profit sharing and contracts of exchange are permissible subject to the elements and conditions of each individual contract...Any bank or financial institution is free to choose to implement any form of contract from either categories for any of its operations in accordance with its 
own circumstances, and in keeping with the Quranic doctrine of "mutual willingness" of the two contracting parties as well as the doctrine of personal freedom of choice to enter into any form of contract... as long as the contract is allowed by Shari'ah. (SCO1 MY)

The scenario described above is an example of how IFIs rationalise the application of spiritual ideals in the development of PLS contracts to suit the practical circumstances in which IFIs are operating. IFIs must consider the structure of their retail operations, to take into account that capital providers/depositors are unlikely to be willing bear any losses on their deposits. The commercial logic guides IFIs to provide security over customer investments, as IFIs face stiff market competition with convetional banking and finance. The income smoothing techniques used by IFIs are somewhat outside of the conventionally understood Shariah boundaries of PLS contracts. However these practices may be seen as inevitable if IFIs are to gain customer trust through their ability to provide stable returns to retail investors. As part of these processes of achieving fabrication, the income smoothing practices enable IFIs to construct socially situated practices of profit and risk sharing transactions. The use accounting reserve, as shown below, enables IFIs to achieve the desired ends by moving the outcomes of the PLS transactions closer to those structure of conventional banking.

Accounting reserves, which includes a profit equalisation reserve and investment risk reserve are component of equity (of either investment account holders (IAH) and/or shareholders) and is constituted by appropriations made out of income...(Accounting guidelines of several IFIs on PLS return)

Profit equalisation reserve - This is the amount appropriated by the Islamic bank out of the mudharabah income, before allocating the mudharib [investor/capital provider] share, in order to maintain a certain level of return on investment for investment account holders and increase owner' equity." (AAOFI Financial Accounting Standard 11, paragraphs 15 and 16)

IFIs use such reserves to guarantee the return on PLS products. IFIs utilise two types of provisions/reserves that reduce the unique risks related to PLS transactions, namely a profit equalization reserve and an investment risk reserve. The use of these reserves acts as income smoothing practices and show how IFIs modify PLS scheme in order to secure a stable IAH profits. These practicea are widely used across IFIs and have become codified as a general accounting standard by the international regulatory bodies of the industry and the central banks in the six countries studied. The Accounting and Auditing Organization for Islamic Financial Institutions codified this accounting treatment on PLS return in their standard/guideline (AAOIFI financial accounting standard No.11 and Islamic Financial Service Board (IFSB) Guidance Note No.3 on profit smoothing).

A typical retail Profit and Loss Sharing Investment Account [PLS in IFIs] involved maturity transformation: account holders can withdraw their money faster than the bank can realise the underlying assets, typically term loans. So if the bank cannot 
match the rates of return available to account holders elsewhere... it may suffer liquidity squeeze or even a run... From the standpoint of financial stability, therefore, smoothing mechanisms like profit equalization reserve do have their attractions (MG2 $-M Y)$

The profit equalization reserve and investment risk reserve consist of amounts set aside to meet future expected payments to investors/capital providers. Profit equalization reserve is allocated to maintain a certain level of return on investment for the investors, while investment risk reserve is designed to stand against future losses for the capital provider. Profit equalization reserve represents appropriations from both IFIs' and investors' profits, whereas the investment risk reserve is exclusively made up of excess investor's returns, IFls do not contribute its own excess returns into the investment risk reserve. In the UK, for example, the regulator insists that deposits should be guaranteed in the way deposits with conventional bank are. An Islamic finance global adviser from Bahrain suggests fabrication of the original PLS contract using profit equalization reserve, IRR and investment guarantee scheme.

"That's not part of the Islamic models. You're not having your deposit guaranteed and get it back when the banks become insolvent. The position at the moment is that the guarantee is offered, and it's the customers who decide to waive it when the banks become insolvent. Another question is, how many of the customers at that stage would be willing to give up the guarantee return of their deposits. (AD1 - BH)

IFIs understand that such smoothing practices are not part of the Islamic model, but in order to satisfy stakeholder desires, they follow the dominant financial logic in the market. The introduction of profit equalization reserves and investment risk reserves into IFIs (as discussed in AAOIFI standard No.11 and IFSB Guidance Note No.3 on profit smoothing) enables IFIs to compete with the conventional banking industry. It provides a shield that IFIs can use to protect their risks such as: displaced commercial risk; withdrawal risks and reputational risks. Several accounting standard setting and regulatory bodies concerned with IFIs in different countries have agreed to codify IFIs translation to the original contract.

Hibah could be considered a 'constructive obligation' under MFRS 137, if the bank has an established practice of paying out a base amount to account holders. In this situation, it should be recognised as a liability equal to the 'best estimate' of what is expected to be paid. If the criteria for constructive obligations are not met, once hibah payments are declared, banks should apply general accounts payable and liability recognition and measurement requirements in respective standards to correctly account for the hibah. (Malaysian Accounting Standard Board Discussion Paper i-3)

IFIs in Malaysia represented in the above discussion paper, and other countries including Indonesia, Bahrain, and Pakistan translate the PLS schemes to suit local market preferences. IFIs 
translation of PLS contracts involves various income smoothing techniques, including hibah (gift), profit equalization reserve, investment risk reserve, or two tier contracts (where IFIs play a mediatory role) to transfer the risks from IFIs to investors/entrepreneurs, or the extreme approach of fixed return in profit and risk sharing contracts to guarantee the return on PLS investments, as shown in the following view.

We are very innovative by having mudharabah [profit and risk sharing schemes] with fixed return, [this is] a genuine style of our jurisdiction.... regulation is not restrictive, enough to ... [prevent] us hav[ing] many innovative and genuine tools... we don't want to get bored [restricted by] the complexity [risks and investment return uncertainty] of the structure [PLS schemes, including mudharabah and musharakah]... (MG3 - ID)

The application of fixed return in PLS as discussed above contravenes the spiritual nature of the scheme, which suggests that the return on the venture/investments is varied depending on the outcome of the investment or venture. The profit equalization reserve/investment risk reserve/gift or other smoothing techniques are used to mediate the recontextualisation of PLS schemes. IFIS involve chains of selection, translation and appropriation of spiritual ideals to reinvent PLS with a pseudo spiritual cachet (Knorr-Cetina, 1981). Pseudo spirituality is represented in the use of income smoothing teachniques to guarantee PLS investment returns. By engaging in the fabrication of PLS investment IFIs mediate the various interests of market players to achieve fixed return from PLS investments. The pseudo PLS schemes represent a technique to achieve a selectively reasoned or modified spiritually based financial alternative (Avgerou \& McGrath, 2007; Halsall \& Brown, 2013; Munro, 2014) via a combination of both the spiritual realm and practical reasoning to create a modern form of spiritual domination at a distance (Latour, 1999b, p. 223; Lowe, 2001; Robson, 1992). Here, accounting mediating role resolves the practical and contextual struggles created by the original PLS accounting.

\subsection{Commodification: how accounting leverages the religious authenticity label}

If a bank has the Islamic label then people tend to trust it. If it doesn't then it tends to get less of a take up. If an Islamic bank drops the Islamic label, from a PR perspective, I think that would probably be a mistake. The label is what is making it uniquely attractive at the moment. (AD2 - UK)

The struggles for IFIs to implement PLS scheme and the pressures to sustain a competitive market position lead to an engagement in spiritual commodification, which seeks ever extended markets, new sources of marketable goods, and expanding profits (McGuire, 2009; York, 2001). IFIs' label of providing spiritual financial alternatives are leveraged to reinvent and repackage pseudo spiritual products (McGuire, 2009). In doing so, accounting is used to leverage claims of religious 
authenticity by selling-off the fabricated products/services to customers or other stakeholders (McGuire, 2010). Accounting information helps to leverage the label IFIs' assets and financing profile. These processes operate in order that fabricated Islamic financial instruments are constructed with similar features to debt-based instruments in conventional banking and finance.

At least in part, IFIs have been able refocus the emphasis on PLS contracts into commodified contracts such as tawarruq (monetization/sales and buy back transactions), bay' bi thaman ajil (sales with installment contracts), bay' al-'inah (sale with immediate repurchase/sale with buy back transaction), or bay' ad- dayn (sales of debt certificates). The IFSB Stability Report (2016) shows a declining trend of PLS product share since 2008. The report describes that the biggest drop in PLS composition was witnessed in Malaysia. Since the Islamic Financial Services Act 2013 prohibits Islamic banks from adding any facilities that would smooth the returns to the capital holders, which removes the deposit protection to PLS types of deposits, the PLS share in Malaysia dropped from $40.87 \%$ in 2013 to $23.48 \%$ in 2014. The preliminary financial highlights of Malaysian sample banks in the second quarter of 2015 indicate that the PLS product share has declined further, to $12.95 \%$. Similar to Malaysia, the United Arab Emirate's PLS share is also declining, from more than $70 \%$ in 2008, it shrank to $50.28 \%$ in 2013 and $42.59 \%$ in 2014.

Any bank or financial institution that operates within that limit is then in complete compliance with Shari'ah, and is "Islamic" irrespective of whether it liberally implements the contract of exchange (RG1 - MY)

Similar to the view presented above, PLS-based financing has to be appropriated from the original spiritual ideals to suit the market appetite (Abdullah, 2012; Maurer, 2002). The IFSB Stability Report (2016) shows that IFIs are now inclined towards alternative sale-based fixed profit deposit products (e.g. commodity murabahah term deposits - a fixed profit rate of return via the buying and selling of commodities as an underlying asset in a sales and buy back transaction) to be able to meet the demand for capital and profit-guaranteed term deposit solutions (Iqbal \& Molyneux, 2016).

The client approaches [an Islamic financial institution] or its affiliate (the 'Bank') and expresses its desire to purchase certain Shariah compliant commodities (the 'Commodities') for agreed amount. The client offers to purchase the Commodities from the Bank on a deferred payment basis. ... The client...appoints an agent (a subsidiary of the Bank), under an Agency Agreement, to sell the Commodities to a broker on behalf of the client, once the client has bought the commodities. .... The Product will be used only if other Shariah compliant modes of finance are not available in the Kingdom of Bahrain. As Shariah teachings discourage taking of debt, the clients are advised that the Product should only be used to meet the genuine need of cash for permissible use. (Shariah Pronouncement for Commodity Murabahah - Islamic Financial Institution Bahrain)

The above Shariah pronouncement is one of the examples of commodity trading by IFIs. It is structured similarly to a loan, where the counterparties are not seriously looking to buy the 
commodity. It is simply a mechanism through which cash is paid, and ultimately repaid at a higher value. It operates as a camouflage for debt based transactions, which makes IFIs products identical to competing conventional products and services (Chong \& Liu, 2009; Kamla, 2009; Mills \& Presley, 1999; Wilson, 2011).

We consider tawarruq (sales and buy back contract) as a non-permissible contract, as it represents a tweak of the exchange contract. Most scholars in different countries disagree with its structure. However, the report that comes to us, including from the Accounting Standard Board, shows that the bank could not 'move and fly' without this contract. At the end we allow the contract to be offered based on the increasing needs with strict requirements. We are taking the middle position, we did not give full permission and we did not prohibit it. It is permitted with very strict requirements. (SB1 -ID)

Accounting information mediates the way financial products are labeled and commodified to minimize risks and maximize profits in financial offerings, as shows in Figure 1 below. In this way PLS contracts can be combined them with alternative fixed returns contracts. The PLS schemes are fabricated through a hybrid combination with a loan type of contract (qard) or a negotiable Islamic debt certificate, as represented in the following guidelines for IFIs balance sheets in Malaysia.

Figure 1 Excerpt of Balance Sheet Format - (IFIs Financial Reporting - Malaysia)

\begin{tabular}{|lc|}
\hline Deposits from customers & $20 X X$ \\
& $R M ' 000$ \\
Savings deposit & \\
Wadiah & $x x x$ \\
Qard & $x x x$ \\
Mudarabah & $x x x$ \\
Hybrid (Wadiah and Mudarabah) & $x x x$ \\
Demand deposit & \\
Wadiah & $x x x$ \\
Qard & $x x x$ \\
Mudarabah & $x x x$ \\
Hybrid (Qard and Mudarabah) & $x x x$ \\
Term deposit & \\
Commodity Murabahah & $x x x$ \\
Negotiable Islamic Debt Certificate (NIDC) & \\
$\quad$ Mudarabah & $x x x$ \\
\hline
\end{tabular}

The combination of PLS and custodianship/agency contracts (hybrid wadiah and mudharabah) require IFIs to take on-board customers PLS based deposits as a loan (qard). The depositor is deemed as a lender, which requires IFIs as borrower to return the precise amount of the PLS investment/deposit when required. Negotiable Islamic debt certificates represent debt issued by IFIs, which includes negotiation on timing of issuance and period. These instruments offer fixed returns over the entire tenure of the investment. Using accounting, IFIs structure and label all agreed contracts to provide guaranteed or fixed returns as described in the following guideline. 
Types of Islamic deposits (e.g. savings, demand and term deposits) and further breakdown by Shariah contracts (e.g. Wadiah, Qard, Murabahah and hybrid.... For hybrid products, a licensed person shall disclose the applicable contracts.... Hybrid contracts are identified as those Islamic deposit products, which combine the application of two or more Shariah contracts that pose differing loss bearing risk to the customer e.g. Wadiah (custodianship) and Mudharabah (loss bearing). (Bank Negara Malaysia Guidelines for IFls Financial Reporting - issued 28 June 2013)

Such types of spiritual commodification occur when spiritual beliefs are seen as part of organizational products/services portfolios (McGuire, 2009; Moore, 2002). IFls establish a spiritual re interpretation, which represents spiritual wisdom on the modified instruments that perfectly fit with the acceptable practice. In one view IFIs may be seen to reinvigorate contemporary spirituality from the oppressive bonds of traditional religious forms. Spiritual reinterpretations become something expanded in response to the prospect of mutually beneficial contracting instruments, where parties are free to accept or reject the original religious ideals. We see this as being represented in this advisors statement.

So far Islamic finance has probably been more successful in offering an alternative perspective on finance than in providing a substantively different way of financing. The emphasis of its theory on social consciousness, risk-sharing, redistribution of wealth and opportunity, and making finance the servant and not the master of the real economy are what many observers want to hear. But Islamic finance has found it hard to put theory into practice. Why? The list of reasons ranges from history, law, politics, regulation, taxation, consumer behavior, and beyond. But an important reason is that Islamic finance is generally made to fit into a system designed for conventional finance, and in the process of making concessions, it seems to lose what its critics regard as its substance. (AD1 - MY)

In line with this statement and our analysis above, El-Gamal (2006, pp. 148-149) defines such commodification of PLS schemes as 'Shariah arbitrage', in which IFIs seem to forbid debt-based transactions, but then permits it in modified form. Using accounting practices, IFIs argue that the typical PLS based balance sheet contains inherent risks related to such quasi-liability products (IAH or other forms of PLS deposits), which could threaten their financial security (Van Greuning \& Iqbal, 2008). These concerns over the reported financial and investment risk have been used defend the reinterpretation of alternative financial instruments that IFIs would normally offer.

IFIs argue that in order to provide alternative finance, the stability of financial position and mitigation of investments risk is a key strategy for the business. IFIs further engage in a more flexible development of hybrid products including deposit and debt-based financial instruments (represented in the proforma balance sheet, Figure 1). The commodification becomes a practical solution that uses legal devices to restructure interest-bearing debt in the form of rent or sales with mark-up transactions that combine 'interest free' certification (El-Gamal, 2007). In this process the religious rules are translated and modified in response to internal and external pressures. 
It is the solution that's provided today. Everybody is happy with it. Unfortunately it is a closed box, and we found commodity sales with paper-backed transactions. But you cannot have the industry without any solutions for now. The alternative is a transparent commodity paid paper... If you really want to challenge us for that, you can't find any alternatives...(RG1 - BH in an Islamic finance global conference)

The narrative above shows how fixed income and profit and risk sharing become translations of one another. They transform PLS schemes into a totally different structure that they previously aimed to avoid. The current PLS schemes shares similar structure to debt-based financing. Accounting mediates the adjustment of Shariah principles governing PLS to suit the industry and market appetite. The nature of accounting inscription as mobile, stable, and combinable enables IFIs to modify the original PLS products (Qu \& Cooper, 2011; Robson, 1992). Accounting allows PLS contracts to be modified and appropriated into hybrid and debt-based instruments.

... The issue of how Shariah can support the development of equity-based financing is an issue that affects the growth of the industry. We have been very much biased toward debt-based financing, which is compliant by any standard. (AD1 - OM)

Overall, accounting mediates IFIs to resolve struggles to maintain, at least the semblance of, PLS schemes. The pseudo PLS schemes allow IFIs to fabricate and commodify accounting techniques/tools that suits both market and regulatory logics. From a regulatory perspective, Archer and Karim (2009) explore similar changes of PLS in various countries. The sound of avoiding interest echoing from the religious imperative seems to be slowly disappearing as the IFIs have justified a fixed return that represents an interest based transaction as a new alternative, as represented in the following statement. In the UK, there is no specific accounting regulation in relation to income smoothing for PLS schemes. However, the regulator requires IFIs to classify PLS investment accounts into contractually 'capital certain', which requires IFIs to guarantee the investments using financial services compensation schemes. These practices show the dual role of accounting in both creating and resolving struggles in PLS practices wherever they clash with the regulatory and market logics.

In Malaysia, Bahrain and Abu Dhabi, the regulatory bodies and the industry supervisor require IFIs to manage unrestricted PLS in such a way as to avoid passing losses onto the capital providers/investors, and also to stabilise the periodic returns paid to them. The use of accounting to mediate pseudo spiritual financial products/services is partly supported by those religious scholars who are sympathetic to the expansion of IFIs. Accounting enables translation and modification of the meaning of spiritual rules around PLS. The role of accounting in the commodification of religious ideals and fabrication of 'acceptable' financial products mediates interactions with the modern banking environment and provides PLS schemes to match market appetite. 


\section{Discussion}

Our paper explores the infusion of religion or spiritual beliefs in IFIs as part modern financial institutions. IFIs engage in pseudo spiritual finance by selectively recontextualising the Islamic financial schemes and appropriating the substance of religious prescription. In practice, the religious rules guiding PLS schemes clashes with the characteristic of the modern capitalist ethos. To resolve the struggles IFIs engage in modifications of the spiritual framework effectively, in instances such as PLS products, mirroring its conventional counterpart. Based on the findings of this research, we extend the discussion of the role of accounting as a mediator of conflicting interests and intentions in infusing spirituality in modern organization. We reconsider how accounting mediates the tensions created by the search for spiritual perfection, and how accounting practices create a space for the mediation of conflicting interests and intentions in the following sections.

\subsection{Accounting in-tension in the search for spiritual perfection: mediating the reinvention of pseudo spirituality}

We argue that accounting plays a role in mediating the struggle to perfect the infusion of spirituality into modern organizations. We provide a more nuanced perspective on the complexity of this relationship within our research setting (Hardy \& Ballis, 2005) by showing how accounting works to reinvent pseudo spiritual finance as a new vision of spiritual perfection. We also provide insight on how accounting mediates the innovative adaptation of spirituality to overcome tensions between the spiritual ethos and the capitalistic hegemony of modern banking and finance (Miller \& Power, 2013; Quattrone, 2015a). Our findings show the use of accounting in enabling spiritual appropriation in the crafting of modern financial instruments.

Accounting is used to resolve struggles in the clashes that we elucidate between IFI ontotheology and the epistemology of modern banking and finance. The latter context is dominated by debt-based financing and there is much less interest in the equity-based and profit and risks sharing instruments more commonly associated with Islamic finance (Maurer, 2002; Rethel, 2010). The findings of our research provide insight by exploring how secular-rational aspects of accounting may sometimes support rather than threaten sacred values (Jacobs \& Walker, 2004).

We also expand the discussion on how accounting acts as an enabling and liberating contributor to religious organizations' spiritual mission (Irvine, 2005). In our case, in the search for spiritual perfection, accounting practices of income smoothing help mediate IFIs selective interpretation of the Shariah rules around PLS. Accounting acts as a mediator in the dynamic redefinition of the sacred law into instruments suited to contemporary finance. The spiritual rules are interpreted and translated to enable alternative banking and financial practices that complement 
or mirror complex modern banking products. In line with Maurer's (2001) argument on IFls involvement in the politic of interpretation, using accounting,

Our research provides insight on how accounting facilitates innovation in the search of spiritual perfection in modern organizations, in our case IFls. Accounting mediates the acts of fabrication and commodification of religious principles in the search for the perfect blending of the spiritual into the organizational setting. IFIs' engagement in pseudo spirituality, in which they organize the fabrication of PLS products using income smoothing techniques and commodification of the original products by arguing the risks involved in the PLS based balance sheet to achieve sustainability in the modern marketplace. The use of accounting enables IFIs to control the dynamic search of the sacred-secular balance in the pursuit of the organizational religious, economic and social imperatives. We show how accounting plays a role in navigating a way through a difficult competitive context where IFIs must maintain consistency in the interpretation and implementation of religious principles. It is through these malleable processes of reinterpretation of what constitutes the sacred-secular divide that concordance to those spiritual ideals is constituted.

\subsection{Accounting's role in providing space for the mediation of conflicting interests and intentions}

We provide insight on how accounting helps to reveal ways in which spirituality can be managed (Miller and Power, 2013; Quattrone, 2015a) by providing space to mediate among various interests in the context of modern organizations. Our findings show how accounting operates to embrace various interests and logics in modern financial institutions. We also provide insight on the way accounting helps to resolve the tensions between an ethical spirituality and the hegemony of financial markets (Johnson, 2017) by revealing accounting interventions around PLS. Accounting provide a space of mediation where the idea of the spiritual alternative offered by IFIs to provide safety and social supports collides with a mainstream view that supports the maximization of shareholders value (Fang, 2014; Pollard \& Samers, 2013). Within the struggles, accounting enables IFIs' efforts to embrace various interests to collectively engage in spiritual modification/appropriation around IFIs retail investment instruments.

Our findings expand discussions of the way accounting works as a tool to exercise and retain control in complex organizational settings (Robbins \& Lapsley, 2015). In our case, accounting mediates the conflicting interests within the contestations that take place in the imagined landscape of IFIs versus the logics and interests embedded in the conventional banking and finance industry (Rethel, 2017). Accounting practices and techniques enable IFIs to reassert some self-control in the struggles around the development of financial instruments on the one hand and religious values on the other (Brentlinger, 2000; Collins, 2007; Tracey, 2012). 
Our research also adds to the discussion in previous studies on the struggles organizations face (Duncan, Flesher, \& Stocks, 1999; Jeavons, 1993; Kuasirikun \& Constable, 2010; Odom \& Boxx, 1988; Zietlow, 1989) by showing how accounting provides space to mediate in working with multiple transcendental values. We do this by exploring the medium used to negotiate a balance between the organization's religious mission and market exigencies (Duncan et al., 1999; Odom \& Boxx, 1988). Accounting practices are used to mediate these clashes between religious principles and market ideals. Accounting to some extent constrains but also shapes IFIs choices to engage in pseudo spiritual practices as an essential part of a process of searching for an acceptable way of retaining or infusing spiritual meaning.

Accounting's role in IFIs pseudo spirituality appears to be unavoidable as they seek to align various interests and competing objectives. Accounting mediates struggles in the process of searching for spiritual perfection by selectively appropriating both the spiritual realm and situated reasoning to extend a modern form of spiritual domination at a distance (Busco \& Quattrone, 2017; Robson, 1992). Accounting resolves the struggles by ensuring the presentation of a product that is different but still recognisable to market participants.

\section{Conclusion and Practical Implications}

This paper argues that IFIs act to organize pseudo spiritual finance practices, in which accounting is deployed in the fabrication and commodification of spirituality. The modification of spiritual referents in PLS schemes presents what seems to remain a stable set of religious prescriptions into something which is different but still the same (Quattrone, 2004) to enable the apparent retention of this form of financing. This process of repackaging spiritual beliefs through fabrication and commodification, such as in the PLS schemes, we describe earlier, is carried out to replicate conventional finance products. The spiritual ideals become a part of the corporate machine, which is utilised by the organization or market as cultural cachet for its own purposes and profit. In this way religious belief may be deprived of its validity to inscribe religious tradition (Carrette \& King, 2005).

We explore the struggles IFIs face to provide spiritual based financial alternatives represented in the PLS schemes that ideally would provide a degree of social betterment for wider society. In responding to competitive market forces IFIs engage in struggles around pseudo spiritual finance as a performative exercise in the modification or enactment of spiritual ideals. The extent to which IFIs offer a financial alternative remains an imaginary landscape in the hegemony of neoliberal economy and finance markets (Fang, 2014; Maurer, 2012; Pitluck, 2012; Rethel, 2017).

Our findings provide an insight for IFIs to reflect on how the institution constitutes the conceptions of religious principles as a spiritual ideal to fulfil the religious imperative that has 
inspired the formation of these alternative-banking institutions. Our observations of and discussion of the practice of interpretation and modification/appropriation of spiritual values could provide a valuable policy reference for IFIs to reflect critically on their institutional practices. These institutions should reconsider their practice in modifying existing financial products that results in the development of complex financialization/financial engineering such as swaps and derivatives. IFIs need to examine whether their products provide the ethical alternative anticipated or simply offers another way to maintain a capitalistic financial hegemony.

A limitation of our study is that we focus on the role of accounting in pseudo-spiritual practices around PLS schemes albeit across various IFIs. Future research could explore other factors and other financial products that may also rely on or influence the adoption of pseudo-spiritual practices. Research may also explore the role of accounting practices in decision making involving more complex structured investment products, such as Islamic derivatives or financial technology based instruments. A focus could be placed on how these products conform to legitimate religious/spiritual ideals and the dynamics within the product development process. Further interesting research exploration around whether 'spirituality' affects accounting in a consistent way or evidence of different effects depending on the religious ideals that each type of spirituality underpins.

In line with Haigh (2006), Forslund \& Bay (2009), McGoun (1997, 2004) McGoun et.al (2003), we recognise that the difficult marriage of IFIs' spiritual aims alongside a profit objective is likely to remain problematic. In the end, the clashes of transcendental values - Islamic values and market values - provides avenues for people to implicitly and explicitly control and redefine the values that serve their chosen aims in specific circumstances. Alternative spiritual forms of financial organizing may best be envisaged as dynamic processes in the midst of complex rationalizations of power and assignment of, or competition for authority.

\section{References}

AAOIFI, A. A. O. f. I. F. I. (2010). Accounting Auditing and Governance Standards for Islamic Financial Institutions. Manama Bahrain.

Abdul-Rahman, A., \& Nor, S. M. (2016). Challenges of profit-and-loss sharing financing in Malaysian Islamic banking. University Kebangsaan Malaysia.

Abdullah, A. (2012). Does Our PLS (Profit and Loss Sharing) Paradigm Resemble Its True Concepts. Retrieved from Malaysia:

Andon, P., Baxter, J., \& Chua, W. F. (2015). Accounting for stakeholders and making accounting useful. Journal of Management Studies, 52(7), 986-1002.

Archer, S., \& Karim, R. A. A. (2009). Profit-sharing investment accounts in Islamic banks: Regulatory problems and possible solutions. Journal of Banking Regulation, 10(4), 300-306. 
Ashforth, B. E., \& Pratt, M. G. (2003). Institutionalized spirituality. Handbook of workplace spirituality and organizational performance, 93-107.

Atmeh, M. A., \& Ramadan, A. H. (2012). A critique on accounting for the mudarabah contract. Journal of Islamic Accounting and Business Research, 3(1), 7-19.

Avgerou, C., \& McGrath, K. (2007). Power, rationality, and the art of living through socio-technical change. MIS quarterly, 295-315.

Badrinarayanan, V., \& Madhavaram, S. (2008). Workplace spirituality and the selling organization: A conceptual framework and research propositions. Journal of Personal Selling \& Sales Management, 28(4), 421-434.

Bigoni, M., Deidda Gagliardo, E., \& Funnell, W. (2013). Rethinking the sacred and secular divide: Accounting and accountability practices in the Diocese of Ferrara (1431-1457). Accounting, Auditing \& Accountability Journal, 26(4), 567-594.

Bigoni, M., \& Funnell, W. (2015). Ancestors of governmentality: Accounting and pastoral power in the 15th century. Critical Perspectives on Accounting, 27, 160-176.

Board, I. F. S. (2016). Islamic Financial Service Industry Stability Report. Retrieved from

Booth, P. (1993). Accounting in churches: a research framework and agenda. Accounting, Auditing \& Accountability Journal, 6(4).

Booth, P. (1995). Management Control in a Voluntary Organization: Accounting and Accountants in Organizational Context: Garland Pub.

Brentlinger, J. (2000). Revolutionizing spirituality: Reflections on Marxism and religion. Science \& Society, 171-193.

Busco, C., \& Quattrone, P. (2015). Exploring how the balanced scorecard engages and unfolds: Articulating the visual power of accounting inscriptions. Contemporary Accounting Research, 32(3), 1236-1262.

Busco, C., \& Quattrone, P. (2017). In Search of the "Perfect One": How accounting as a maieutic machine sustains inventions through generative 'in-tensions'. Management Accounting Research.

Callon, M. (1984). Some elements of a sociology of translation: domestication of the scallops and the fishermen of St Brieuc Bay. The Sociological Review, 32(1_suppl), 196-233.

Carmona, S., \& Ezzamel, M. (2006). Accounting and religion: a historical perspective. Accounting History, 11(2), 117-127.

Carrette, J. R., \& King, R. (2005). Selling spirituality: The silent takeover of religion: Psychology Press.

Carroll, J. E. (2012). Sustainability and Spirituality: State University of New York Press.

Cassell, C., \& Lee, B. (2017). Understanding Translation Work: The evolving interpretation of a trade union idea. Organization Studies, 38(8), 1085-1106.

Chenhall, R. H., Hall, M., \& Smith, D. (2013). Performance measurement, modes of evaluation and the development of compromising accounts. Accounting, Organizations and Society, 38(4), 268-287.

Chong, B. S., \& Liu, M.-H. (2009). Islamic banking: interest-free or interest-based? Pacific-Basin Finance Journal, 17(1), 125-144.

Chua, W. F. (1995). Experts, networks and inscriptions in the fabrication of accounting images: a story of the representation of three public hospitals. Accounting, Organizations and Society, 20(2), 111-145.

Collins, R. (2007). The classical tradition in sociology of religion. Beckford, J. e Demmerath III. NJ (Orgs.) The Sage Handbook of the Sociology of Religion. London: Sage, 19-38.

Cordery, C. (2006). Hallowed treasures: sacred, secular and the Wesleyan Methodists in New Zealand, 1819-1840. Accounting History, 11(2), 199-220.

DiVanna, J. A., Sreih, A., \& Ainley, M. (2009). A new financial dawn: The rise of Islamic finance: Leonardo and Francis Press.

Diwany, T. E. (Ed.) (2010). Islamic Banking and Finance: What It Is and What It Could Be. Bolton, United Kingdom: 1st Ethical Charitable Trust. 
Duncan, J. B., Flesher, D. L., \& Stocks, M. H. (1999). Internal control systems in US churches: An examination of the effects of church size and denomination on systems of internal control. Accounting, Auditing \& Accountability Journal, 12(2), 142-164.

El-Gamal, M. A. (2006). Islamic finance: Law, economics, and practice: Cambridge University Press.

El-Gamal, M. A. (2007). Incoherence of contract-based Islamic financial jurisprudence in the age of financial engineering. Wis. Int'l LJ, 25, 605.

Ezzamel, M. (2005). Accounting for the activities of funerary temples: the intertwining of the sacred and the profane. Accounting and business research, 35(1), 29-51.

Fang, E. S. (2014). Islamic finance in global markets: Materialism, ideas and the construction of financial knowledge. Review of International Political Economy, 21(6), 1170-1202.

Forslund, D., \& Bay, T. (2009). The eve of critical finance studies. ephemera: Theory and Politics in Organization, 9(4), 285-299.

Foucault, M. (1982). The subject and power. Critical inquiry, 8(4), 777-795.

Fromm, E. (1947). Man For Himself New York: Rinehart \& Company. 1959.

Fromm, E. (1955). The Sane Society. New York: Holt, Rinehart and Winston: Inc.

Fromm, E. (1976). To Have Or to Be?(World Perspectives Vol. 50, planned and edited by Ruth Nanda Anshen), London (Jonathan Cape) 1978.

Hafeez, D., \& Muhammad, M. (2016). An Analysis of Corporate Entity and Limited Liability in Islamic and Western Perspectives of Corporate Governance. Browser Download This Paper.

Haigh, M. (2006). Social investment: subjectivism, sublation and the moral elevation of success. Critical Perspectives on Accounting, 17(8), 989-1005.

Halsall, R., \& Brown, M. (2013). Askēsis and organizational culture. Organization, 20(2), 233-255.

Hardy, L., \& Ballis, H. (2005). Does one size fit all? The sacred and secular divide revisited with insights from Niebuhr's typology of social action. Accounting, Auditing \& Accountability Journal, 18(2), 238-254.

Hasanuzzaman, S. (1989). Limited Liability of Shareholders: An Islamic Perspective. Islamic Studies, 28(4), 353-361.

Herda, D. N., Reed, S. A., \& Bowlin, W. F. (2013). The relationship between religious beliefs and the accounting and economic practices of a society: Evidence from the Dead Sea Scrolls. Accounting Historians Journal, 40(2), 115-143.

Iqbal, \& Mirakhor. (2007). An introduction to Islamic finance: theory and practice: John Wiley \& Sons (Asia).

Iqbal, M., \& Molyneux, P. (2016). Thirty years of Islamic banking: History, performance and prospects: Springer.

Irvine, H. (2005). Balancing money and mission in a local church budget. Accounting, Auditing \& Accountability Journal, 18(2), 211-237.

Jacobs, K. (2005). The sacred and the secular: examining the role of accounting in the religious context. Accounting, Auditing \& Accountability Journal, 18(2), 189-210.

Jacobs, K., \& Walker, S. P. (2004). Accounting and accountability in the lona Community. Accounting, Auditing \& Accountability Journal, 17(3), 361-381.

Jeavons, T. (1993). The role of values: Management in religious organizations. Governing, leading, and managing nonprofit organizations: New insights from research and practice, 52-76.

Johnson, C. (2017). Commerce and Consumption The Oxford Handbook of the Protestant Reformations: Oxford University Press.

Kamla, R. (2009). Critical insights into contemporary Islamic accounting. Critical Perspectives on Accounting, 20(8), 921-932.

Knorr-Cetina, K. (1981). The manufacture of knowledge: An essay on the constructivist and contextual nature of science: Elsevier.

Kuasirikun, N., \& Constable, P. (2010). The cosmology of accounting in mid 19th-century Thailand. Accounting, Organizations and Society, 35(6), 596-627.

Latour, B. (1986). The powers of association. In J. Law (Ed.), Power, action and belief: a new sociology of knowledge? Routledge and Kegan Paul. 
Latour, B. (1993). Messenger talks. Institute of Economic Research. Retrieved from

Latour, B. (1999a). From fabrication to reality. Pandora's hope. Essays on the reality of science studies.

Latour, B. (1999b). Pandora's hope: essays on the reality of science studies: Harvard University Press.

Laughlin, R. C. (1988). Accounting in its social context: An analysis of the accounting systems of the Church of England. Accounting, Auditing \& Accountability Journal, 1(2), 19-42.

Laughlin, R. C. (1990). A model of financial accountability and the Church of England. Financial accountability \& management, 6(2), 93-114.

Leardini, C., \& Rossi, G. (2013). Accounting and power in religious institutions: Verona's Santa Maria della Scala monastery in the Middle Ages. Accounting History, 18(3), 415-427.

Locke, J., \& Lowe, A. (2007). A Biography: Fabrications in the Life of an ERP Package. Organization, 14(6), 793-814.

Lowe, A. (2001). "Action at a distance": accounting inscriptions and the reporting of episodes of clinical care. Paper presented at the Accounting Forum.

Maslow, A. (1965). Self-actualization and beyond.

Maslow, A. H. (1943). A theory of human motivation. Psychological review, 50(4), 370.

Maurer, B. (2001). Engineering an Islamic future. Anthropology Today, 17(1).

Maurer, B. (2002). Anthropological and accounting knowledge in Islamic banking and finance: rethinking critical accounts. Journal of the Royal Anthropological Institute, 8(4), 645-667.

Maurer, B. (2003). Uncanny exchanges: the possibilities and failures ofmaking change'with alternative monetary forms. Environment and Planning D, 21(3), 317-340.

Maurer, B. (2012). The Disunity of Finance: Alternative Practices to Western Finance. The Oxford Handbook of the Sociology of Finance, 413.

McGoun, E. G. (1997). Hyperreal finance. Critical Perspectives on Accounting, 8(1), 97-122.

McGoun, E. G. (2004). Form, function, and finance: architecture and finance theory. Critical Perspectives on Accounting, 15(8), 1085-1107.

McGoun, E. G., Dunkak, W. H., Bettner, M. S., \& Allen, D. E. (2003). Walt's street and Wall Street: theming, theater, and experience in finance. Critical Perspectives on Accounting, 14(6), 647661.

McGuire, T. (2009). From emotions to spirituality:"Spiritual labor" as the commodification, codification, and regulation of organizational members' spirituality. Management Communication Quarterly.

McGuire, T. (2010). From emotions to spirituality: "Spiritual labor" as the commodification, codification, and regulation of organizational members' spirituality. Management Communication Quarterly, 24(1), 74-103.

McPhail, K., Gorringe, T., \& Gray, R. (2005). Crossing the great divide: critiquing the sacred secular dichotomy in accounting research. Accounting, Auditing \& Accountability Journal, 18(2), 185 188.

Meyer, J. W. (1986). Social environments and organizational accounting. Accounting, Organizations and Society, 11(4-5), 345-356.

Miller, P., \& Power, M. (2013). Accounting, Organizing, and Economizing: Connecting Accounting Research and Organization Theory. The Academy of Management Annals, 7:1, 557-605. doi:10.1080/19416520.2013.783668

Miller, W. W. (2002). Durkheim, Morals And Modernity: Taylor \& Francis.

Mills, P. S., \& Presley, J. R. (1999). The Prohibition of Interest in Western Literature Islamic Finance: Theory and Practice (pp. 101-113): Springer.

Moore, T. (2002). The soul's religion: Cultivating a profoundly spiritual way of life: HarperCollins New York.

Munro, I. (2014). Organizational ethics and Foucault's 'art of living': Lessons from social movement organizations. Organization Studies, 35(8), 1127-1148.

Nagaoka, S. (2009). Reconsidering Mudaraba Contracts in Islamic Finance: What is the Economic Wisdom (Hikma) of Partnership-based Instruments? 
Neimark, M. K. (1994). Regicide revisited: Marx, Foucault and accounting. Critical Perspectives on Accounting, 5(1), 87-108.

Odom, R. Y., \& Boxx, W. R. (1988). Environment, planning processes, and organizational performance of churches. Strategic Management Journal, 9(2), 197-205.

Paisey, C., \& Paisey, N. J. (2011). Visibility, governance and social context: Financial management in the Pre-Reformation Scottish church. Accounting, Auditing \& Accountability Journal, 24(5), 587-621.

Parker, L. D. (2001). Reactive planning in a Christian Bureaucracy. Management Accounting Research, 12(3), 321-356.

Pitluck, A. Z. (2012). Islamic Banking and Finance: Alternative or Facade? The Oxford Handbook of the Sociology of Finance, 431.

Pollard, J., \& Samers, M. (2013). Governing Islamic finance: Territory, agency, and the making of cosmopolitan financial geographies. Annals of the Association of American Geographers, 103(3), 710-726.

Presser, S. B. (1992). Thwarting the Killing of the Corporation: Limited Liability, Democracy, and Economics. Nw. UL Rev., 87, 148.

Qu, S. Q., \& Cooper, D. J. (2011). The role of inscriptions in producing a balanced scorecard. Accounting, Organizations and Society, 36(6), 344-362.

Quattrone, P. (2004). Accounting for God: accounting and accountability practices in the Society of Jesus (Italy, XVI-XVII centuries). Accounting, Organizations and Society, 29(7), 647-683.

Quattrone, P. (2015a). Governing Social Orders, Unfolding Rationality, and Jesuit Accounting Practices:A Procedural Approach to Institutional Logics. Administrative science quarterly, 60(3), 411-445. doi:10.1177/0001839215592174

Quattrone, P. (2015b). In search of what accounting is not: speculations on the future of valuing, transparency, and a new aesth-etics for governing capitalism and democracy. A Research Agenda for Management \& Organization Studies. Cheltenham: Elgar, 1-25.

Rethel, L. (2010). Whose legitimacy? Islamic finance and the global financial order. Review of International Political Economy, 18(1), 75-98. doi:10.1080/09692290902983999

Rethel, L. (2017). The imaginary landscapes of Islamic finance and the global financial crisis. Chapters, 562-579.

Rethel, L. (2018). Corporate Islam, Global Capitalism and the Performance of Economic Moralities. New Political Economy, 1-15.

Robbins, G., \& Lapsley, I. (2015). From secrecy to transparency: Accounting and the transition from religious charity to publicly-owned hospital. The British Accounting Review, 47(1), 19-32.

Robson, K. (1992). Accounting numbers as "inscription": action at a distance and the development of accounting. Accounting, Organizations and Society, 17(7), 685-708.

Shanmugam, B., \& Perumal, V. (2005). Governance issues and Islamic banking.

Shanmugam, B., \& Zahari, Z. R. (2009). A primer on Islamic Finance.

Shapiro, B. (2009). A comparative analysis of theological and critical perspectives on emancipatory praxis through accounting. Critical Perspectives on Accounting, 20(8), 944-955.

Swanson, G., \& Gardner, J. C. (1986). The inception and evolution of financial reporting in the Protestant Episcopal Church in the United States of America. The Accounting Historians Journal, 55-63.

Thomas, A. S., Cox, S., \& Kraty, B. (2005). Structuring Islamic Finance Transactions: Euromoney Books.

Tomkins, C., \& Karim, R. A. A. (1987). The Shari'ah and Its Implications for Islamic Financial Analysis: An Opportunity to Study Interactions Among Society, Organizations, and Accounting. American Journal of Islamic Social Sciences, 4(1), 101.

Tracey, P. (2012). Religion and organization: A critical review of current trends and future directions. The Academy of Management Annals, 6(1), 87-134.

Uusmani, M. T. (2002). An introduction to Islamic finance (Vol. 20): Brill.

Valantasis, R., \& Wimbush, V. L. (2002). Asceticism: Oxford University Press.

Van Greuning, H., \& Iqbal, Z. (2008). Risk analysis for Islamic banks: World Bank Publications. 
Vogel, F. E., \& Hayes, S. L. (1998). Islamic Law and Finance: Religion, Risk, and Return: Kluwer Law Internat.

Warde, I. (2010). Islamic finance in the global economy: Edinburgh University Press.

Weber, M., \& Eisenstadt, S. N. (1968). On Charisma and Institution Building: University of Chicago Press.

Wilson, R. (2011). Islamic banking and finance in North Africa: Past development and future potential.

York, M. (2001). New Age commodification and appropriation of spirituality. Journal of Contemporary Religion, 16(3), 361-372.

Zietlow, J. T. (1989). Capital and operating budgeting practices in pure nonprofit organizations. Financial accountability \& management, 5(4), 219-232. 